\title{
POC-SCALE TESTING OF OIL AGGLOMERATION TECHNIQUES AND EQUIPMENT FOR FINE COAL PROCESSING
}

\section{Quarterly Technical Progress Report No. 8}

\section{April 1, 1998 - June 30, 1998}

Principal Investigators

W. Pawlak

K. Szymocha

AUGUST 1998

Work Performed Under Contract No. DC-A22-95PC95152

Prepared by

Alberta Research Council

Environmental Technologies

250 Karl Clark Road

Edmonton, Alberta

Canada T6N 1E 


\section{DISCLAIMER}

*This report was prepared as an account of work sponsored by an agency of the United States Government. Neither the United States Government nor any agency thereof, nor any of their employees, makes any warranty, express or implied, or assumes any legal liability or responsibility for the accuracy, completeness, or usefulness of any information, apparatus, product, or process disclosed, or represents that its use would not infringe privately owned rights. Reference herein to any specific commercial product, process, or service by trade name, trademark, manufacturer, or otherwise does not necessarily constitute or imply its endorsement, recommendation, or favoring by the United States Government or any agency thereof. The views and opinions of authors expressed herein do not necessarily state or reflect those of the United States Government or any agency thereof*. 


\begin{abstract}
This report covers the technical progress achieved from April 1, 1998 to June 30, 1998 on the POCScale Testing of Oil Agglomeration Techniques and Equipment for Fine Coal Processing.

Continuous bench-scale runs were carried out with Luscar Mine coal. The main objectives were to optimize process conditions for a proposed jet processor and to compare its performance with a standard high-shear mixer. A total of three runs consisted of 15 testing periods was carried out. Both conditioning devices performed very well with combustible matter recovery exceeding 96\%. Slightly higher coal recovery was observed for high-shear mixer, while lower ash contents were achieved when jet processor was used for coal conditioning.

During the current reporting period work has been continued and completed on the engineering and design package of a $3 \mathrm{t} / \mathrm{h}$ POC-scale agglomeration unit. Preliminary design package prepared by Thermo Design Engineering, a subcontractor to this project, was submitted to DOE for revision and approval.
\end{abstract}




\section{EXECUTIVE SUMMARY}

During the current reporting period there were activities relative to the following tasks:

- Task 1 - Project Planning and Management

- Subtask 2.5 - POC Equipment Installation, Shakedown and Commissioning plan

- Task 4 - Coal Characterization and Laboratory (batch) and Bench-scale Testing

- Task 5 - Final Engineering and Design of POC-Scale Equipment

- Task 9 - Process Evaluation

The activities under Task 1 are not technical and are not described in this report. Following is the description of work carried out under other listed tasks.

\section{Subtask 2.5}

Work has been completed on preparation of manual for POC-scale equipment installation, operation and maintenance. The document was submitted to DOE for comments and/or suggestions.

\section{Task 4}

During this reporting period a total of three runs was carried out. Each run consisted of several testing periods that differed in process conditions and in type of the conditioning device.

Runs were described as follows:

- The Aglofloat Process Performance at High and Medium Oil Concentrations - Test L-5

- Test with Reduced Coal Recovery - Test L-6

- The Aglofloat Process Performance at Low Oil Concentration - Test L-7.

An extensive sampling was carried out during all testing periods. For the process performance evaluation three indicators i.e. combustibles recovery, ash reduction and tailings ash content were taken into consideration.

During each testing period samples were also taken from each individual flotation cell to determine coal concentrate distribution along flotation bank and its quality in terms of ash content. Performance of bench-scale flotation machine was also verified by confirmatory batch-scale tests using a conditioned slurry taken from continuous unit.

Based on the results obtained for tests L-5, L-6, and L-7 it has been concluded that replacement of the high-shear mixer with a jet processor resulted in:

- a slight decrease in combustibles recovery

- negligible product quality improvement

It was also determined that:

- time required to fully stabilize the plant operation after the major process parameter changes is 1.5 hours 
- process performance reproducibility is very good

- results of the batch flotation confirmatory tests are in a good agreement with the pilot plant test results.

\section{Task 5}

Based on the specification package prepared by ARC, Thermo Design Engineering designed a Proofof-Concept (POC-Scale) agglomeration unit to be demonstrated and tested at a commercial coal preparation plant. The unit is designed for a nominal capacity throughput of $3 \mathrm{t} / \mathrm{h}$ of dry coal fines and is capable of being operated on a short daily schedule or longer $24 \mathrm{~h} /$ day basis.

Copies of the preliminary POC equipment and design package were submitted to DOE Contract Manager, and under separate cover to ADD Document Control Office. 


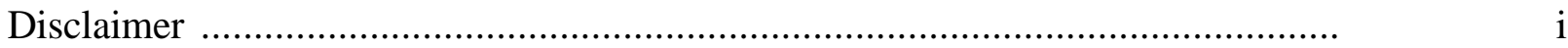

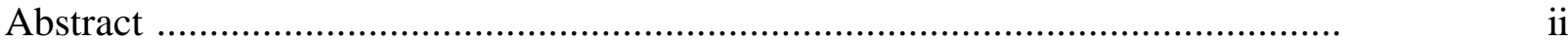

Executive Summary .......................................................................

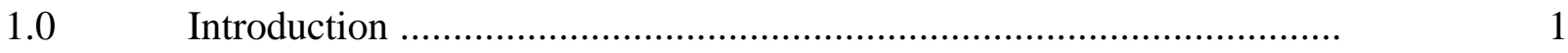

2.0 Continuous Bench-Scale Testing …..............................................

$2.1 \quad$ Test Facility ......................................................................

$2.2 \quad$ Materials ................................................................

$2.3 \quad$ Test Conditions ...............................................................

$2.4 \quad$ Pilot Plant Tests ...............................................................

2.4.1 The Aglofloat Process Performance at High and Medium Oil Concentrations - Test L-5 ..................... 4

2.4.2 Test with Reduced Coal Recovery - Test L-6 .............. 8

2.4.3 The Aglofloat Process Performance at Low Oil Concentration - Test L-7 .................................... 11

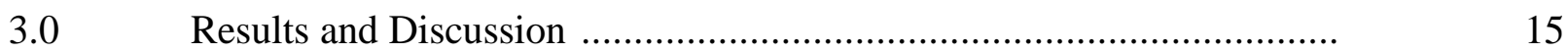

3.1 Coal Grinding System Stability ..................................... 15

Flotation Performance Evaluation ..................................... 16

$3.3 \quad$ Tests Reproducibility ......................................................

3.4 Batch-scale Flotation Confirmatory Tests ............................ 23

3.5 Comparison of High-Shear Mixer and Jet Processor

Design Package ............................................................. 25

List of Abbreviations and Acronyms.................................................... 26

\section{List of Figures}

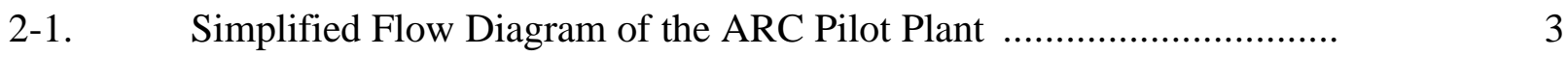

2-2. $\quad$ Process Performance for Test L-5 ........................................... 6

2-3. $\quad$ Coal Concentrate Distribution Along Flotation Bank at Oil Concentration of $2.5 \%$ - Test L-5 .............................................

2-4. Coal Concentrate Distribution Along Flotation Bank at Oil Concentration $1.6 \%$ - Test L-5 ...............................................

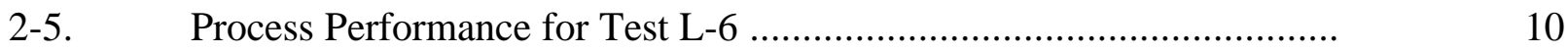

2-6. $\quad$ Process Performance for Test L-7 ............................................. 12

2-7. Coal Concentrate Distribution Along Flotation Bank at Oil Concentration of $0.75 \%$ - Test L-7 
3-1. Flotation Stage Performance - Ash Content and Yield for Cumulative Products for Cells from \#1 to \#6, Oil Concentration of $2.5 \%$ (Test L-5)

3-2. Flotation Stage Performance - Ash Content and Yield for Cumulative Products for Cells from \#1 to \#6, Oil Concentration of 1.6\% (Test L-5)

3-3. Flotation Stage Performance - Ash Content and Yield for Cumulative Products for Cells from \#1 to \#6,Oil Concentration of $0.75 \%$ (Test L-7)

3-4. Coal Concentrate Distributions and Ash Contents Along Flotation Bank at Oil Concentration of $1.6 \%$ (Test L-5).

3-5. Coal Concentrate Distribution Along Flotation Bank for High-Shear Mixer and Jet Processor at Oil Concentration of $1.5 \%$ and no frother addition (Test L-6)

3-6. Flotation Cell Performance Reproducibility at Oil Concentration of $1.5 \%$

3-7. Flotation Cell Performance Reproducibility without Frother at Oil Concentration of $1.5 \%$

\section{List of Tables}

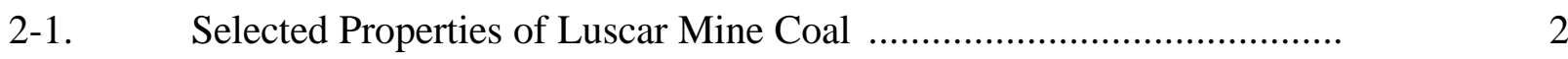

2-2. $\quad$ Pilot Plant Test Results - Test L-5 .............................................

2-3. Coal Concentrate Distribution Along Flotation Bank (sampling time 1 min.) ................................................................................. 5

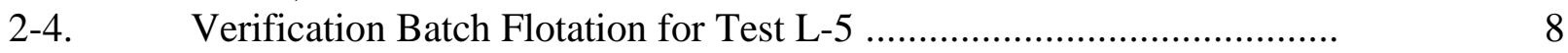

2-5. Pilot Plant Test Results - Test L-6 .............................................

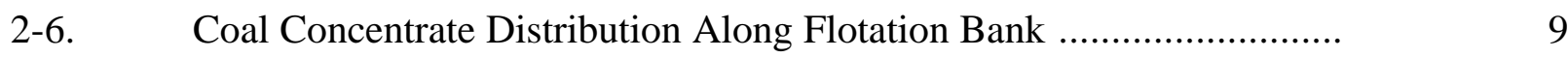

2-7. $\quad$ Pilot Plant Test Results - Test L-7 ..........................................

2-8. Coal Concentrate Distribution Along Flotation Bank (1 min sampling

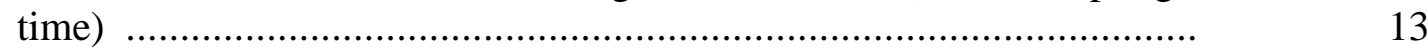

2-9. Verification Batch Flotation for Test L-7 ................................... 14

3-1. Feed Coal Particle Size Distribution for Rods Charge of $150 \mathrm{~kg} \ldots \ldots \ldots . .15$

3-2. Coal Concentrate Distribution and Ash Contents Along Flotation Bank .......................................................................................

3-3. Test Reproducibility for Different Conditions ............................... 21

3-4. $\quad$ Flotation Cell Reproducibility at Medium Oil Concentration for High-

3-5. Comparison of the Flotation Verification Batch-Scale Tests with Pilot

3-6. Effect of Operating Conditions on Process Performance....................... 24 


\subsection{INTRODUCTION}

This report covers the technical progress achieved form April 1, 1998 to June 30, 1998 on the Proof-ofConcept (POC) Scale Testing of Oil Agglomeration Techniques and Equipment for Fine Coal Processing project, under FETC/DOE Contract No. DE-AC22-95PC95152.

The major objectives of the work carried out under this project are:

- further advancement of oil agglomeration techniques, and

- development of new conditioning equipment

for fine coal processing and recovery.

Currently less than half of the fine coal fraction [minus $600 \mu \mathrm{m}(28 \mathrm{mesh})$ ] generated at the coal commercial preparation plants is subjected to cleaning and recovery, while the remaining fines are sent to slurry ponds. This scenario is caused by the lack of an effective beneficiation process to treat coal fines and, what is of great importance, the absence of a permanent market for coal fines. During the last few years, an extensive R\&D program to solve the coal fines utilization problem led to new concepts and developments. One of the possibilities for fine coal utilization is the preparation of a coal-water slurry that could be co-fired with conventional pulverized coal at power generation station. Significant advancement in this area was made by the Pennsylvania Electric Company which demonstrated this concept and conducted a series of combustion tests on a utility-scale boiler.

Another problem with recovered fine coal is its resistance to dewatering. This is especially important if fines are to be combined with the coarse clean coal. Excessive moisture content in the recovered fines could have a negative impact on the final moisture of the plant product and may increase it above contract specs agreed upon by the coal producer and coal utilizer. Recently, significant progress was made in the selection and application of surfactants to aid the dewatering of clean-coal fines. Vacuum filtration of the coal slurries with a specific surfactant is capable of producing filter cakes containing about $12 \%$ of moisture.

The work undertaken under this contract is directed towards enhancement of the oil agglomeration technology and development of agglomerating equipment. The patented Aglofloat ${ }^{\circledR}$ technology was selected for this project. This process results in the successful treatment of coal fines at high combustibles recovery. A second goal is to develop new equipment, which could replace currently used high-shear mixers. Under this program, a new device, namely a jet processor, is proposed. To provide a baseline for jet processor performance, the parallel testing of both high-shear mixer and jet processor will be conducted. Initial testing is carried out at in a $250 \mathrm{~kg} / \mathrm{h}$ bench-testing facility, which is an ongoing activity. The results achieved to date from batch- and bench-scale testing were utilized for preparation of the design specification for $3 \mathrm{t} / \mathrm{h}$ POC-scale equipment. Preliminary engineering and a design package were prepared during the current reporting period. Work also commenced on preparation of manuals for POC-scale equipment installation, operation and maintenance, and development of a testing plan for this unit. 


\subsection{CONTINUOUS BENCH-SCALE TESTING}

\subsection{Test Facility}

Bench-scale continuous testing is carried out at a $250 \mathrm{~kg} / \mathrm{h}$ integrated agglomeration test facility. The description of the unit and test procedure were presented in detail in Quarterly Technical Progress Report No. 6. A flow diagram of the unit is shown in Figure 2-1.

\subsection{Materials}

All runs were performed using the following materials:

- Luscar Mine coal fines

- diesel oil as a bridging liquid, and

- methyl isobutyl carbinol (MIBC) as a frother

Luscar Mine coal is medium volatile bituminous in rank and is mined from a seam located in the Rocky Mountain Foothills of Western Alberta. Full proximate and ultimate compositions of this coal were presented in Report No. 6. The following table provides only its selected properties that are of importance from the coal utilization point of view.

Table 2-1. Selected Properties of the Luscar Mine Coal

\begin{tabular}{|l|c|}
\hline Property & Value \\
\hline Moisture, wt \% (ar) & 3.1 \\
Ash, wt \% (db) & 16.5 \\
Volatile Matter, wt \% (db) & 25.7 \\
Fixed Carbon, wt \% (db) & 54.7 \\
Sulfur, wt \% (daf) & 0.38 \\
Calorific Value, (db) MJ/kg (Btu/lb) & $28.6(12,300)$ \\
\hline
\end{tabular}

Note: ar - as received $\mathrm{db}-$ dry basis

\subsection{Test Conditions}

During this reporting period a total of three runs were carried out. Each run consisted of several testing periods that differed in some process conditions and/or utilized either the high-shear mixer or jet processor for coal conditioning. The target test conditions were as follows:

- coal throughput - $250 \mathrm{~kg} / \mathrm{h}$

- coal slurry concentration in the rod mill - $50 \%$ (dry coal basis)

- coal slurry concentration at the conditioning stage - $20 \%$ (dry coal basis)

- coal slurry concentration at the flotation stage - $6 \%$ (dry coal basis)

- frother (MIBC) addition - $250 \mathrm{~g}$ per ton of dry coal

- jet processor injection pressure - $650 \mathrm{kPa}$ 


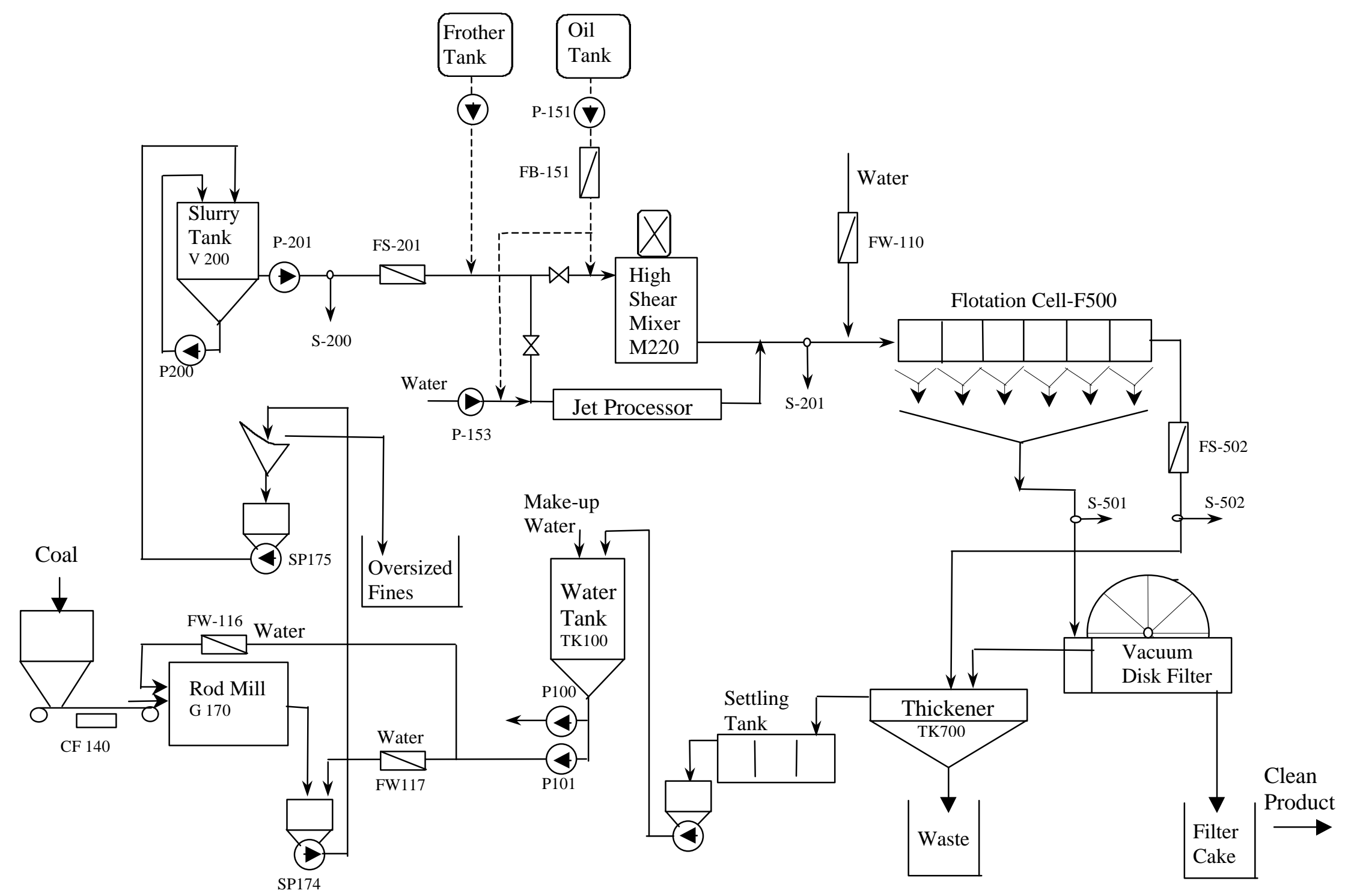

Figure 2-1. Simplified Flow Diagram of the ARC Pilot Plant. 
The actual conditions achieved during the testing periods are included in the tables presenting the test results.

\subsection{Pilot Plant Tests}

\subsubsection{The Aglofloat Process Performance at High and Medium Oil Concentrations - Test L-5}

The objectives of the L-5 test were as follows:

- comparison of the high-shear mixer and jet processor performance at high and medium oil concentrations

- investigation of the system response using a step function for the oil concentration

Test L-5 was conducted to investigate the effect of exchanging a high-shear mixer with a jet processor and to establish a baseline performance for the Aglofloat process. The main indicators of performance were combustibles recovery, tailings ash and ash reduction.

Test L-5 consisted of five testing periods. During two initial testing periods, the high-shear mixer performance was compared with a jet processor performance at the oil concentration of $2.5 \%$. These two periods were followed by a short, third period $(30 \mathrm{~min})$ with no oil used for coal conditioning. A transition period between third and fourth periods was used for the observation of system response for sudden change of process conditions. During the fourth and fifth testing periods the baseline performances for both conditioning devices were established at a medium oil concentration of $1.6 \%$. The solids concentration throughout all testing periods was kept steady in the range from $18 \%$ to $21 \%$. The results for test L-5 are presented in Table 2-2 and Figure 2-2.

The comparison of process performances during the first and second periods showed that the replacement of the high-shear mixer with a jet processor caused a slight reduction in combustibles recovery from $98 \%$ to $96.5 \%$ and the tailings ash content decreased from $85.5 \%$ to about $80 \%$. Similar trends were observed at a medium oil concentration during periods four and five but the replacement of conditioning devices resulted in only negligible combustibles recovery change from about of $98.4 \%$ for the high-shear mixer to $98.1 \%$ for the jet processor. A small change in tailings ash content from $85.1 \%$ for the high-shear mixer to $82.4 \%$ for the jet processor was also observed.

Figure 2-3 shows the flotation product distribution for both conditioning devices. 
Table 2-2. Pilot Plant Test Results - Test L-5

Target Process Conditions:

Luscar Mine Coal, Mill Rods Charge - $150 \mathrm{~kg}$,

Slurry Solids Concentration $\quad-20 \%$

Flotation Cell Solids Concentration - 6\%

Oil Concentration Period $1(8: 30-10.05)-2.5 \%$ HS

Period 2 (10:05-12:05) $-2.5 \%$ Jet

Frother $250 \mathrm{~g} / \mathrm{t}$

Period 3 (12:05-12:35) - No oil

Period 4 (12:40-14:45) - $1.5 \%$ Jet

Period 5 (14:45-16:15) - 1.5\% HS

"

\begin{tabular}{|c|c|c|c|c|c|c|c|c|c|c|c|c|}
\hline \multirow[t]{2}{*}{$\begin{array}{c}\text { Sampling } \\
\text { Time }\end{array}$} & \multirow[t]{2}{*}{ Option } & \multirow[t]{2}{*}{$\begin{array}{c}\text { Oil } \\
\text { Concn }\end{array}$} & \multirow[t]{2}{*}{ Frother } & \multicolumn{2}{|c|}{$\begin{array}{l}\text { Feed Slurry } \\
\text { S } 201\end{array}$} & \multicolumn{2}{|c|}{$\begin{array}{l}\text { Product } \\
\text { S } 501\end{array}$} & \multicolumn{2}{|c|}{$\begin{array}{c}\text { Tailings } \\
\text { S } 502\end{array}$} & \multirow[t]{2}{*}{ Yield } & \multirow[t]{2}{*}{ Rec. } & \multirow[t]{2}{*}{$\overline{A R}$} \\
\hline & & & & $\mathrm{Cs}$ & Ash & $\mathrm{Cs}$ & Ash & $\mathrm{Cs}$ & Ash & & & \\
\hline 8:30 Start & - & $\%$ & $\mathrm{~g} / \mathrm{t}$ & $\%$ & $\%$ & $\%$ & $\%$ & $\%$ & $\%$ & $\%$ & $\%$ & $\%$ \\
\hline 9:05 & HS & 2.59 & 240 & 21.3 & $18.8^{*}$ & 24.2 & 11.5 & 0.8 & 85.0 & 90.1 & 98.2 & 38.7 \\
\hline $9: 35$ & HS & 2.39 & 229 & 20.5 & $19.0^{*}$ & 24.2 & 10.0 & 1.0 & 86.1 & 88.2 & 98.0 & 46.8 \\
\hline 10:05 & HS & 2.35 & 230 & 20.7 & $16.4^{*}$ & 24.0 & 9.2 & 0.9 & 85.6 & 90.5 & 98.4 & 44.0 \\
\hline $10: 35$ & Jet & 2.42 & 192 & 19.4 & 17.9 & 26.9 & 9.7 & 0.8 & 79.9 & 88.3 & 97.1 & 45.7 \\
\hline 11:05 & Jet & 2.53 & 230 & 19.2 & 17.5 & 26.2 & 9.7 & 0.8 & 79.9 & 88.9 & 97.3 & 44.7 \\
\hline $11: 35$ & Jet & 2.50 & 326 & 19.2 & 17.6 & 26.7 & 10.0 & 0.9 & 79.0 & 89.0 & 97.2 & 42.9 \\
\hline $12: 05$ & Jet & 2.48 & 202 & 18.8 & 17.9 & 25.2 & 10.1 & 0.9 & 73.2 & 87.6 & 96.0 & 43.6 \\
\hline $12: 35$ & Jet & No oil & 237 & 18.4 & 18.2 & - & 9.2 & 7.3 & 20.8 & 17.5 & 24.6 & 49.8 \\
\hline 13:10 & Jet & 1.54 & 240 & 20.7 & 16.7 & 24.5 & 10.8 & 0.9 & 82.0 & 91.7 & 98.2 & 35.6 \\
\hline $13: 45$ & Jet & 1.41 & 247 & 20.6 & 17.5 & 21.7 & 11.3 & 1.1 & 82.4 & 91.4 & 98.2 & 35.2 \\
\hline $14: 15$ & Jet & 1.56 & 268 & 20.6 & 16.5 & 26.6 & 10.1 & 1.0 & 81.3 & 91.0 & 98.0 & 39.0 \\
\hline $14: 45$ & Jet & 1.72 & 233 & 20.4 & 17.9 & 23.6 & 11.1 & 1.1 & 83.4 & 90.6 & 98.1 & 37.9 \\
\hline $15: 15$ & HS & 1.71 & 236 & 19.1 & 17.2 & 23.1 & 10.7 & 0.9 & 83.3 & 91.0 & 98.2 & 37.7 \\
\hline $15: 45$ & HS & 1.78 & 228 & 18.1 & 17.3 & 24.1 & 10.7 & 0.8 & 85.1 & 91.2 & 98.4 & 37.9 \\
\hline $16: 15$ & HS & 1.62 & 240 & 20.5 & 16.9 & 23.5 & 11.2 & 0.9 & 85.2 & 92.3 & 98.6 & 33.8 \\
\hline
\end{tabular}

Note: Average ash for the S-200/201slurry samples $-17.5 \%$

Ash content of the composite dry coal sample $\quad-18.3 \%$

* Sample S-200 instead of S-201 used

Table 2-3. Coal Concentrate Distribution Along Flotation Bank (sampling time $1 \mathrm{~min}$.)

\begin{tabular}{|c|c|c|c|c|c|c|c|c|c|c|c|c|c|}
\hline \multirow[t]{2}{*}{ Time } & \multirow[t]{2}{*}{$\begin{array}{l}\text { Option } \\
\& \text { Oil } \\
\text { Concn }\end{array}$} & \multicolumn{2}{|c|}{ Cell \#1 } & \multicolumn{2}{|c|}{ Cell \#2 } & \multicolumn{2}{|c|}{ Cell \#3 } & \multicolumn{2}{|c|}{ Cell \#4 } & \multicolumn{2}{|c|}{ Cell \#5 } & \multicolumn{2}{|c|}{ Cell \#6 } \\
\hline & & Yield & Ash & Yield & Ash & Yield & Ash & Yield & Ash & Yield & Ash & Yield & Ash \\
\hline & $\%$ & $\%$ & $\%$ & $\%$ & $\%$ & $\%$ & $\%$ & $\%$ & $\%$ & $\%$ & $\%$ & $\%$ & $\%$ \\
\hline $9: 50$ & HS 2.5 & 82.1 & 12.1 & 13.3 & 14.6 & 2.7 & 26.4 & 0.8 & 34.4 & 0.7 & 61.9 & 0.4 & 70.7 \\
\hline 11:50 & Jet 2.5 & 64.2 & 8.5 & 23.6 & 11.1 & 8.0 & 16.0 & 2.6 & 25.1 & 1.3 & 40.8 & 0.3 & 42.6 \\
\hline $12: 35$ & no oil & 10.5 & 7.0 & 10.7 & 6.2 & 11.7 & 6.0 & 7.3 & 5.15 & 12.4 & 6.3 & 47.4 & 12.4 \\
\hline $14: 40$ & Jet 1.6 & 67.3 & 9.8 & 22.4 & 12.0 & 6.6 & 17.5 & 2.3 & 29.4 & 1.0 & 48.9 & 0.5 & 59.3 \\
\hline 16:10 & HS 1.6 & 84.1 & 11.5 & 11.7 & 14.9 & 2.5 & 29.0 & 0.7 & 33.7 & 0.6 & 65.6 & 0.4 & 70.6 \\
\hline
\end{tabular}




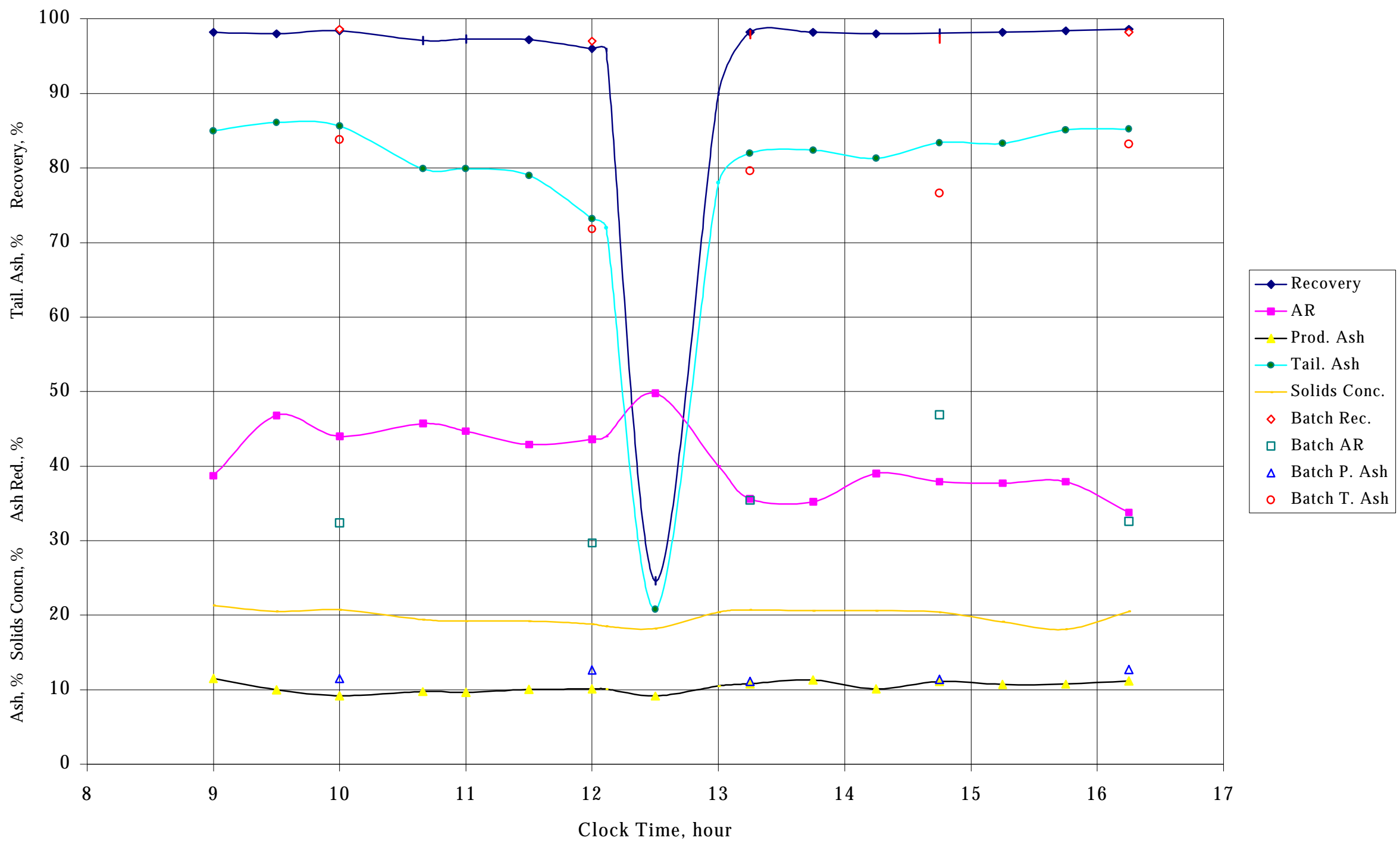

Figure 2-2. Process Performance for Test L-5 


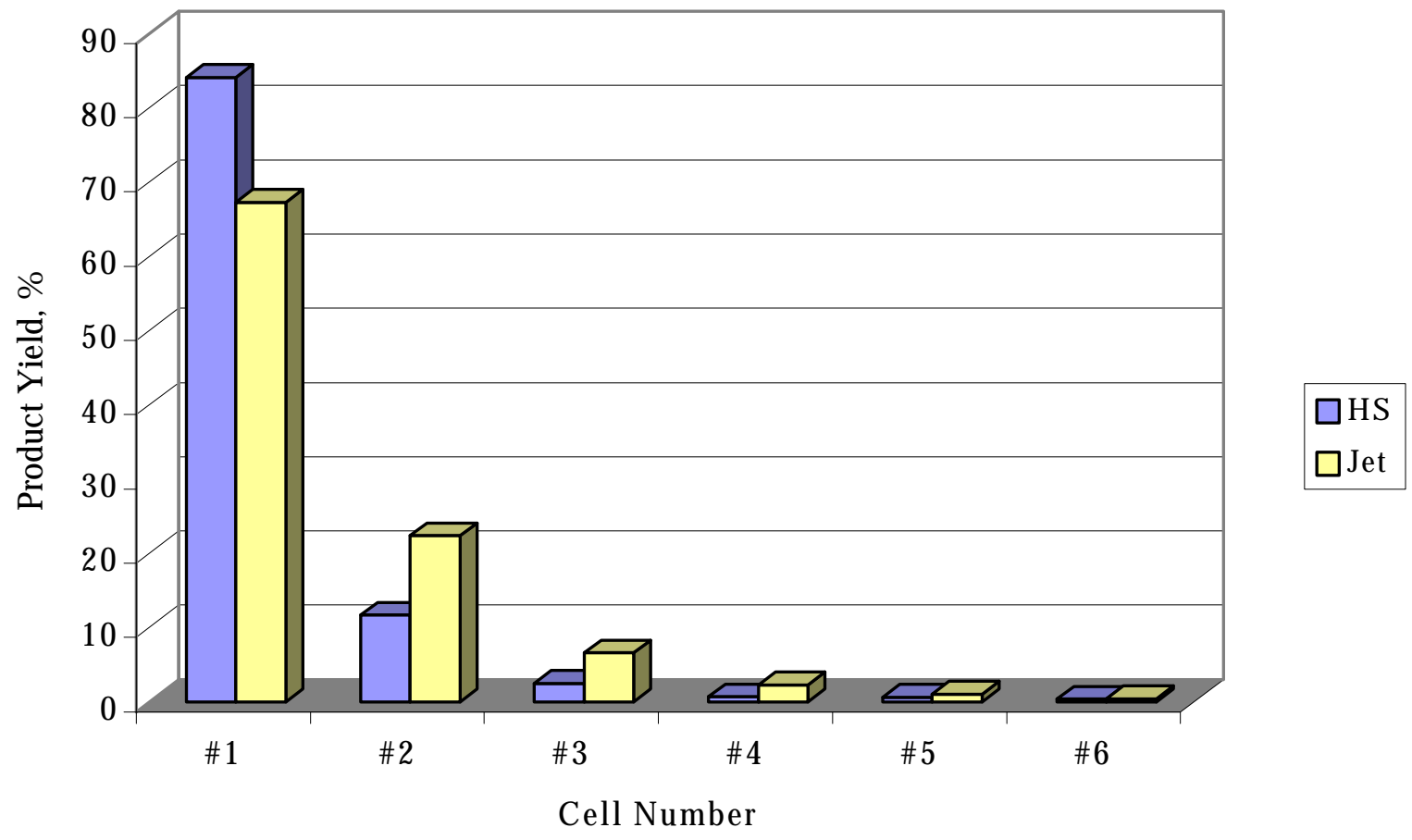

Figure 2-3. Coal Concentrate Distribution Along Flotation Bank at Oil Concentration of $2.5 \%$ - Test L-5

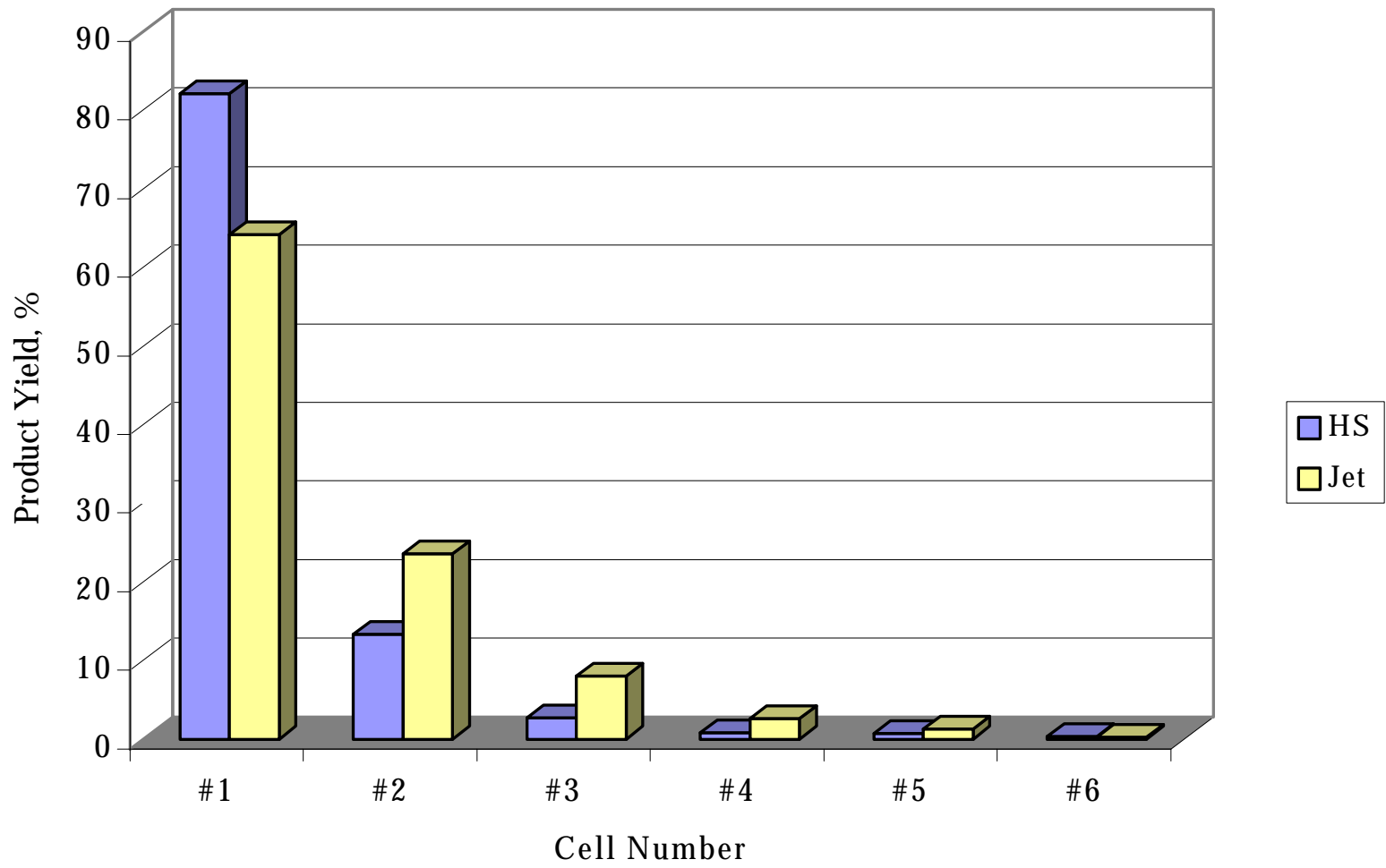

Figure 2-4. Coal Concentrate Distribution Along Flotation Bank at Oil Concentration of $1.6 \%$ - Test L-5 
During the L-5 test, in order to verify flotation performance and to determine the scale-up factor, for each testing period, small (1 L) samples of the conditioned slurry were taken from the system for the batch-scale flotation confirmatory tests. The test results are shown in Table 2-4. The comparison of the batch test results with pilot plant data (see Figure 2-2) shows a very good agreement in terms of combustibles recovery, but product ash contents for batch tests are higher and tailings ash content are slightly lower.

Table 2-4. Verification Batch Flotation for Test L-5

Process Conditions

High-Shear Mixer: $\quad$ Plant Sample Cs: $20 \% \quad$ Oil: Diesel

Flotation Cell: $\quad 6 \mathrm{~min}, 1100 \mathrm{rpm}, \quad$ Cs: $6.5 \% \quad$ Frother: $\quad$ MIBC $250 \mathrm{~g} / \mathrm{t}$

\begin{tabular}{|c|c|c|c|c|c|c|c|c|}
\hline Time & $\begin{array}{c}\text { Option \& } \\
\text { Oil Concn } \\
\%\end{array}$ & $\begin{array}{c}\text { Solids Concn } \\
\%\end{array}$ & $\begin{array}{c}\text { Feed Coal } \\
\text { Ash } \\
\%\end{array}$ & $\begin{array}{c}\text { Product } \\
\text { Ash } \\
\%\end{array}$ & $\begin{array}{c}\text { Tailings } \\
\text { Ash } \\
\%\end{array}$ & $\begin{array}{c}\text { Yield } \\
\%\end{array}$ & Rec. & AR \\
\hline $10: 05$ & HS 2.35 & 20.3 & 17.0 & 12.7 & 83.8 & 92.9 & 98.6 & 32.4 \\
\hline $12: 05$ & Jet 2.48 & 18.0 & 18.0 & 11.5 & 71.8 & 91.3 & 97.0 & 29.7 \\
\hline $13: 15$ & Jet 1.52 & 18.9 & 17.1 & 11.1 & 79.6 & 91.4 & 97.9 & 35.4 \\
\hline $14: 40$ & Jet 1.70 & 20.0 & 21.4 & 11.4 & 76.6 & 90.7 & 97.3 & 46.9 \\
\hline $16: 15$ & HS 1.62 & 19.2 & 18.9 & 12.7 & 83.2 & 91.5 & 98.2 & 32.6 \\
\hline
\end{tabular}

\subsubsection{Test with Reduced Coal Recovery - Test L-6}

Test objectives of the L-6 test were as follows:

- to determine the pilot plant process performance without frother addition

- to compare the performance of high-shear mixer and jet processors

It was expected that the reduced process performance, resulting from the absence of a frother, would enhance differences between the different conditioning equipment. The data obtained for "no frother" conditions were useful for the system dynamic response investigation and stabilization time determination in the next test (see test L-7). Process conditions for test L-6 are shown in Table 2-5. The run L-6 consisted of two testing periods. During the first period high-shear mixer was used for coal conditioning. During a second period the jet processor was used at similar oil concentration. The results obtained during the first period were considered as a reference performance level against which to compare the data obtained when working with jet processor. The test results and process performance are shown in Table 2-5 and Figure 2-5.

For the process performance evaluation three indicators i. e. combustibles recovery, ash reduction and tailings ash content were taken into consideration. Out of these three parameters the tailings ash content was expected to be the most responsive for the process conditions. 
Table 2-5. Pilot Plant Test Results - Test L-6

Target Process Conditions:

Luscar Mine Coal, Rods Mill Charge - $150 \mathrm{~kg}$,

Coal Slurry Solids Concentration $\quad-20 \%$

Flotation Cell Solids Concentration - $6 \%$

Frother Additon

$-0 \mathrm{~g} / \mathrm{t}$

Oil Concentration Period $1(9: 45-12: 00)-1.5 \%$ HS

Period 2 (12:00-14:00) $-1.5 \%$ Jet

\begin{tabular}{|c|c|c|c|c|c|c|c|c|c|c|}
\hline \multirow[t]{2}{*}{$\begin{array}{c}\text { Sampling } \\
\text { Time }\end{array}$} & \multirow[t]{2}{*}{$\begin{array}{l}\text { Option \& } \\
\text { Oil Concn }\end{array}$} & \multicolumn{2}{|c|}{$\begin{array}{c}\text { Slurry } \\
\text { S 200/201 }\end{array}$} & \multicolumn{2}{|c|}{$\begin{array}{c}\text { Product } \\
\text { S } 501\end{array}$} & \multicolumn{2}{|c|}{$\begin{array}{c}\text { Tailings } \\
\text { S } 502\end{array}$} & \multirow[t]{2}{*}{ Yield } & \multirow[t]{2}{*}{ Rec. } & \multirow[t]{2}{*}{$\mathrm{AR}$} \\
\hline & & Cs & Ash & Cs & Ash & $\mathrm{Cs}$ & Ash & & & \\
\hline $\mathrm{hr}$ & $\%$ & $\%$ & $\%$ & $\%$ & $\%$ & $\%$ & $\%$ & $\%$ & $\%$ & $\%$ \\
\hline $10: 15$ & HS 1.16 & 25.0 & 19.1 & 31.6 & 7.9 & 2.9 & 44.2 & 69.2 & 78.8 & 58.4 \\
\hline $10: 45$ & HS 1.32 & 22.0 & 17.8 & 29.8 & 7.4 & 3.0 & 46.5 & 73.5 & 82.7 & 58.2 \\
\hline $11: 15$ & HS 1.44 & 20.0 & 19.0 & 29.5 & 7.7 & 2.3 & 50.8 & 73.7 & 84.0 & 59.7 \\
\hline 11:45 & HS 1.52 & 19.1 & 19.2 & 30.8 & 7.8 & 2.0 & 49.9 & 72.8 & 83.2 & 59.6 \\
\hline $12: 30$ & Jet 2.08 & 13.3 & 20.7 & 28.3 & 8.3 & 1.4 & 50.3 & 70.4 & 81.4 & 60.0 \\
\hline $13: 00$ & Jet 1.79 & 15.2 & 21.7 & 28.3 & 8.0 & 1.1 & 52.6 & 69.3 & 81.4 & 62.9 \\
\hline $13: 30$ & Jet 1.46 & 18.3 & 19.5 & 27.6 & 7.8 & 1.5 & 48.3 & 71.1 & 81.4 & 60.2 \\
\hline 14:00 & Jet 1.39 & 19.2 & 20.1 & 30.2 & 7.9 & 1.9 & 48.6 & 70.0 & 80.7 & 60.7 \\
\hline
\end{tabular}

Note: Average ash for the S-200/201slurry samples $-18.9 \%$

Ash content of the composite dry coal sample $\quad-19.2 \%$

The results obtained showed only slight differences in the process performance when switching from one type of conditioning device to another. The combustibles recovery for the high-shear mixer was about $83.5 \%$. Application of the jet processor for "no frother" conditions resulted in slightly lower combustibles recovery in the order of $81 \%$. There was no significant difference in the tailings ash content for both conditioning devices. In terms of the ash reduction, the results for the jet processor are slightly better $(61 \%)$ as compared with the high-shear mixer $(59 \%)$.

Table 2-6 (see also Figure 3-4) shows the flotation cells product distribution for both conditioning devices.

Table 2-6. Coal Concentrate Distribution Along Flotation Bank

\begin{tabular}{|c|c|c|c|c|c|c|c|c|c|c|c|c|}
\hline \multirow{2}{*}{$\begin{array}{c}\text { Sampl. } \\
\text { Time }\end{array}$} & \multicolumn{2}{|c|}{ Cell \#1 } & \multicolumn{2}{c|}{ Cell \#2 } & \multicolumn{2}{c|}{ Cell \#3 } & \multicolumn{2}{c|}{ Cell \#4 } & \multicolumn{2}{c|}{ Cell \#5 } & \multicolumn{2}{c|}{ Cell \#6 } \\
& Yield & Ash & Yield & Ash & Yield & Ash & Yield & Ash & Yield & Ash & Yield & Ash \\
\cline { 2 - 14 } & $\%$ & $\%$ & $\%$ & $\%$ & $\%$ & $\%$ & $\%$ & $\%$ & $\%$ & $\%$ & $\%$ & $\%$ \\
\hline 11:30 HS & 39.1 & 7.8 & 23.8 & 9.2 & 20.1 & 10.2 & 7.5 & 10.4 & 7.3 & 12.2 & 2.1 & 12.8 \\
\hline 13:45 Jet & 34.7 & 7.6 & 24.1 & 7.6 & 19.4 & 8.4 & 10.1 & 8.9 & 9.7 & 9.8 & 2.0 & 10.3 \\
\hline
\end{tabular}




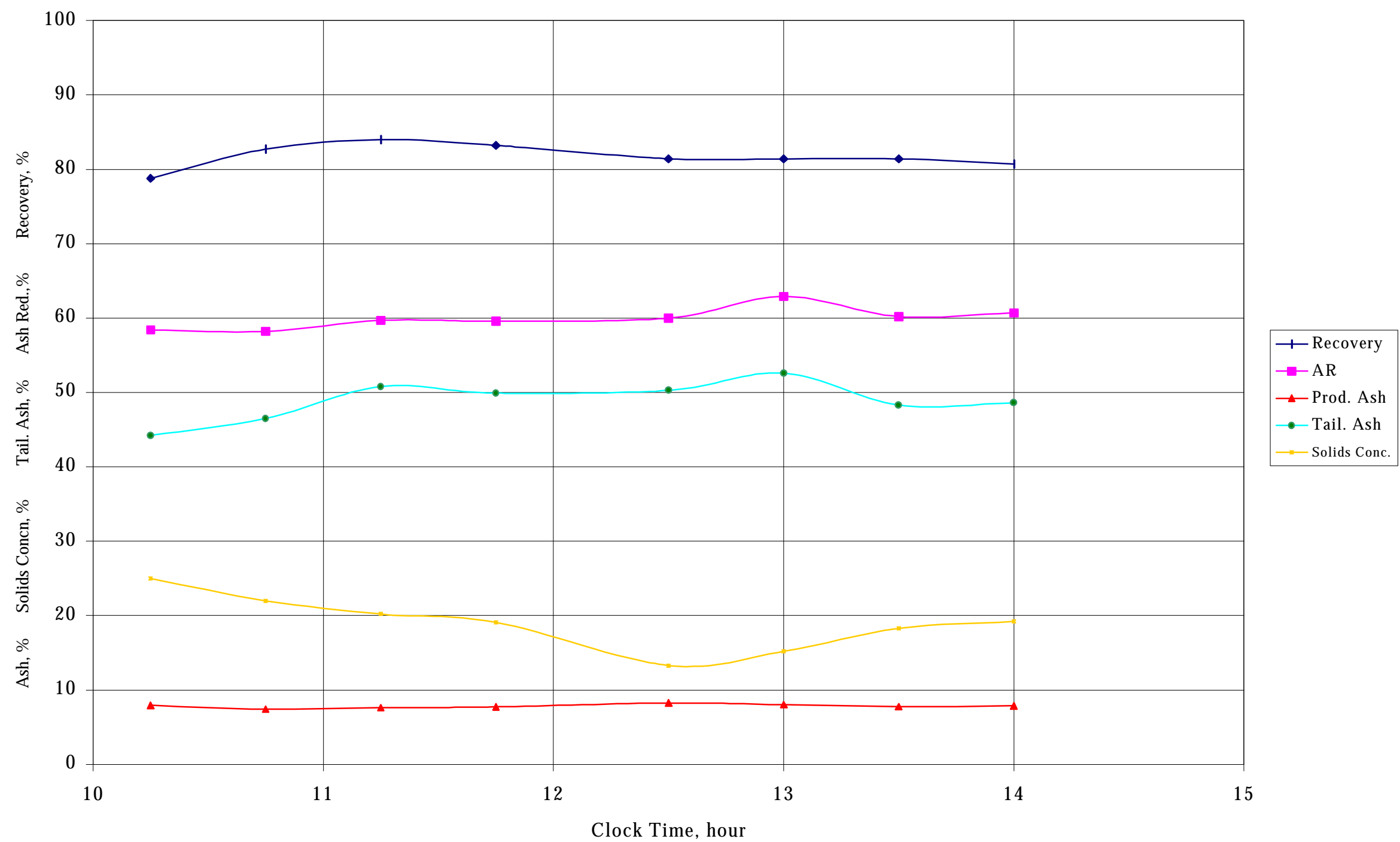

Figure 2-5. Process Performance for Test L-6 


\subsubsection{The Aglofloat Process Performance at Low Oil Concentration - Test L-7.}

Test objectives of the test L-7 were as follows:

- to compare the performance of the high-shear mixer and jet processors at a low oil concentration

- to determine the plant response dynamics and test results reproducibility

Process conditions for test L-7 are shown in Table 2-7. This run consisted of four testing periods. The initial two periods were used for baseline performance and stability determination. The third and fourth periods were used for response dynamics and performance reproducibility. The test results are shown in Table 2-7 and in Figure 2-6.

Table 2-7. Pilot Plant Test Results - Test L-7

Targeted Test Conditions:

Luscar Mine Coal, Rod Mill Charge - $150 \mathrm{~kg}$,

Coal Slurry Solids Concentration - 20\%

Flotation Cell Solids Concentration - 6\%

Oil Concentration Period $1(8: 45-11: 00)-0.75 \%$ HS

Period $2(11: 00-13: 30)-0.75 \%$ Jet

Period 3 (13:30-15:00) - 0.75\% HS

Period 5 (15:00-16:30) - 1.5\% HS

Frother $250 \mathrm{~g} / \mathrm{t}$

$250 \mathrm{~g} / \mathrm{t}$

(No Frother)

$0 \mathrm{~g} / \mathrm{t}$

$250 \mathrm{~g} / \mathrm{t}$

\begin{tabular}{|c|c|c|c|c|c|c|c|c|c|c|c|}
\hline \multirow[t]{2}{*}{$\begin{array}{c}\text { Sampl. } \\
\text { Time }\end{array}$} & \multirow[t]{2}{*}{ Option } & \multirow[t]{2}{*}{$\begin{array}{c}\text { Oil } \\
\text { Concn }\end{array}$} & \multicolumn{2}{|c|}{$\begin{array}{l}\text { Feed Slurry } \\
\text { S } 201\end{array}$} & \multicolumn{2}{|c|}{$\begin{array}{c}\text { Product } \\
\text { S } 501\end{array}$} & \multicolumn{2}{|c|}{$\begin{array}{c}\text { Tailings } \\
\text { S } 502\end{array}$} & \multirow[t]{2}{*}{ Yield } & \multirow[t]{2}{*}{ Rec. } & \multirow[t]{2}{*}{ AR } \\
\hline & & & Cs & Ash & Cs & Ash & Cs & Ash & & & \\
\hline & & $\%$ & $\%$ & $\%$ & $\%$ & $\%$ & $\%$ & $\%$ & $\%$ & $\%$ & $\%$ \\
\hline $9: 30$ & HS & 0.76 & 22.2 & 20.2 & 31.9 & 12.0 & 0.8 & 85.3 & 88.8 & 97.9 & 40.8 \\
\hline $10: 00$ & HS & 0.75 & 21.6 & 20.0 & 22.5 & 12.4 & 0.9 & 85.5 & 89.6 & 98.1 & 37.9 \\
\hline $10: 30$ & HS & 0.75 & 23.2 & 19.2 & 25.7 & 11.7 & 1.3 & 85.1 & 89.8 & 98.1 & 39.1 \\
\hline $11: 00$ & HS & 0.74 & 21.9 & 18.7 & 24.8 & 11.8 & 1.3 & 86.2 & 90.7 & 98.4 & 37.1 \\
\hline $11: 30$ & Jet & 0.82 & 20.3 & 18.0 & 25.2 & 11.9 & 0.9 & 83.9 & 91.5 & 98.3 & 34.1 \\
\hline $12: 00$ & Jet & 0.84 & 20.2 & 18.4 & 25.4 & 10.5 & 1.1 & 83.9 & 89.3 & 97.9 & 42.7 \\
\hline $12: 30$ & Jet & 0.84 & 20.4 & 19.7 & 25.2 & 11.6 & 0.9 & 83.4 & 87.2 & 97.3 & 41.4 \\
\hline $13: 00$ & Jet & 0.77 & 22.3 & 19.1 & 26.5 & 10.3 & 1.3 & 83.7 & 88.0 & 97.6 & 46.3 \\
\hline $13: 30$ & Jet & 0.76 & 22.5 & 18.4 & 11.1 & 10.3 & 1.2 & 83.8 & 88.9 & 97.8 & 44.4 \\
\hline $14: 00$ & $\begin{array}{l}\text { Jet No } \\
\text { Frother }\end{array}$ & 0.77 & 22.9 & 19.1 & 29.8 & 9.4 & 2.3 & 53.8 & 78.1 & 87.5 & 50.9 \\
\hline $14: 30$ & $\begin{array}{l}\text { Jet No } \\
\text { Frother }\end{array}$ & 0.74 & 23.2 & 19.5 & 31.3 & 8.4 & 2.4 & 52.4 & 74.9 & 85.2 & 56.7 \\
\hline $15: 00$ & $\begin{array}{l}\text { Jet No } \\
\text { Frother }\end{array}$ & 0.69 & 24.7 & 21.7 & 31.2 & 8.8 & 2.7 & 51.0 & 69.5 & 81.0 & 59.4 \\
\hline $15: 30$ & HS & 1.46 & 25.3 & 21.4 & 25.5 & 12.8 & 1.3 & 84.1 & 87.9 & 97.6 & 40.2 \\
\hline $16: 00$ & HS & 1.46 & 25.2 & 20.2 & 23.4 & 12.1 & 1.3 & 84.9 & 88.8 & 97.9 & 40.3 \\
\hline $16: 30$ & HS & 1.50 & 24.2 & 18.5 & 24.0 & 11.3 & 1.2 & 85.9 & 90.4 & 98.3 & 38.6 \\
\hline
\end{tabular}




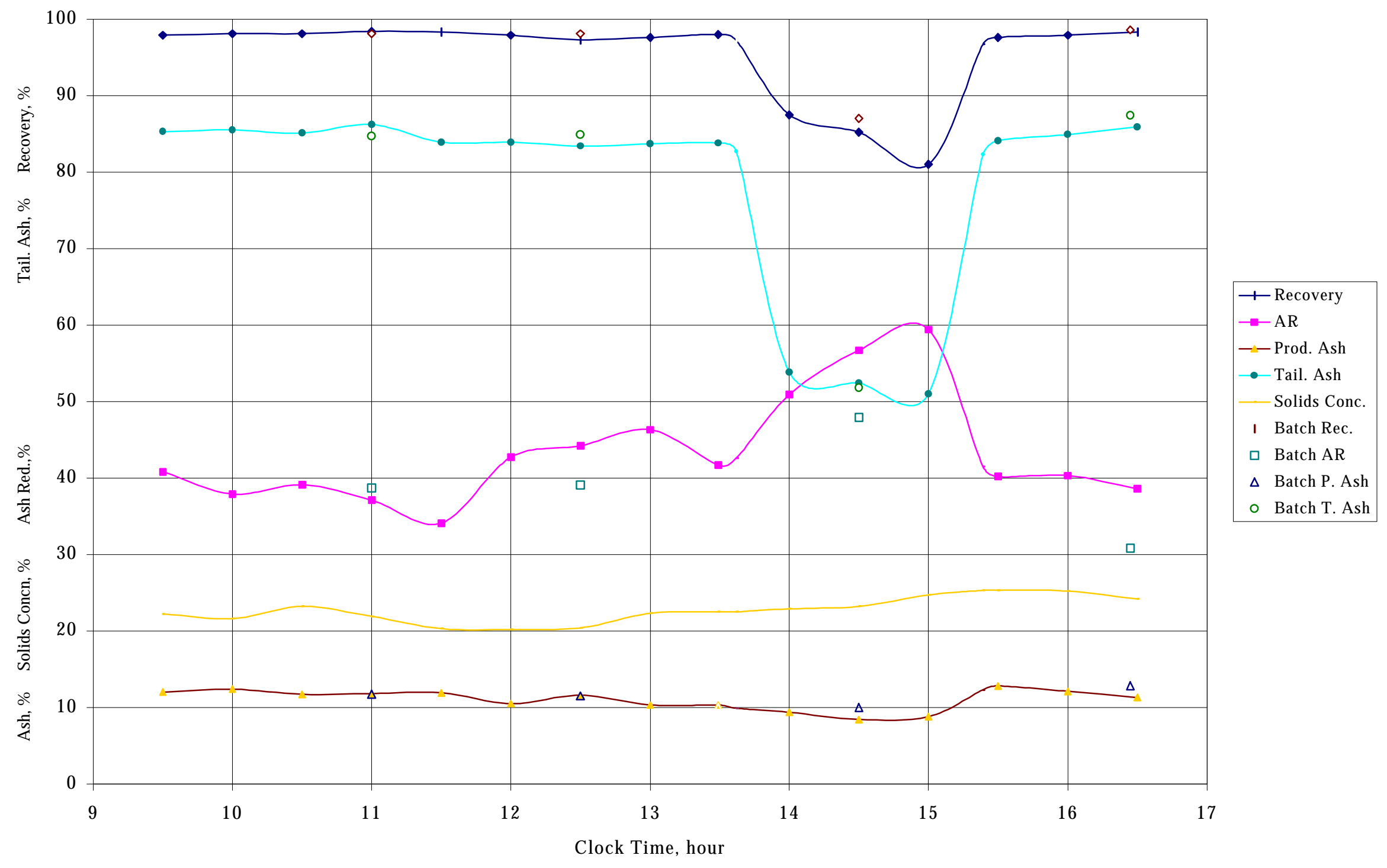

Figure 2-6. Process Performance for Test L-7 
During the first period, the high-shear mixer was used for slurry conditioning at an oil concentration of $0.75 \%$. In a second period the high-shear mixer was replaced with the jet processor. The time for the second period was extended to two and half hours to gather more data on the system performance and stability. As shown in Figure 2-6, the operation of the plant was very stable. The fluctuations in the combustibles recovery and tailings ash content were negligible. Application of the high-shear mixer resulted in combustibles recovery of $98.3 \%$. The coal recovery for the jet processor was slightly lower and was about $97.6 \%$. The difference observed for the tailings ash content was $1.6 \%$ (85.3\% for the mixer and $83.7 \%$ for the jet processor). In terms of ash reduction, the results for the jet processor were better $(43.7 \%)$ as compared with the high-shear mixer $(38 \%)$. These findings were confirmed by differences in the product ash content in the samples collected from individual flotation cells.

During the third period, the oil concentration was kept at the same level as in the two previous periods but frother flow to the jet processor was stopped to find out the time required for process performance stabilization. The reference performance for "no frother" conditions was known from test L-6. The dynamics of the system response to the new process conditions are shown in Figure 2-6. It could be seen that a 1.5 hour operation is a sufficient time to stabilize the system after major changes in process parameters. In the fourth period, the jet processor was replaced with high-shear mixer and oil concentration was increased to $1.5 \%$ to repeat the process conditions used in the fifth period of test L5. This testing period was carried out to confirm the process performance reproducibility.

An agreement between these two testing periods in terms of combustibles recoveries and tailings ash contents is very good (see Figure 2-6 - fourth period and Figure 2-2 - fifth period results).

Table 2-8 and Figure 2-7 show flotation cells product distribution for the high-shear mixer and jet processor. The results obtained are in good agreement with those obtained in test L-5 (see Figures 2-3 and 2-4).

Table 2-8. Coal Concentrate Distribution Along Flotation Bank (1 min sampling time)

\begin{tabular}{|c|c|c|c|c|c|c|c|c|c|c|c|c|c|}
\hline Samp & Option & \multicolumn{2}{|c|}{ Cell \#1 } & \multicolumn{2}{|c|}{ Cell \#2 } & \multicolumn{2}{|c|}{ Cell \#3 } & \multicolumn{2}{|c|}{ Cell \#4 } & \multicolumn{2}{|c|}{ Cell \#5 } & \multicolumn{2}{|c|}{ Cell \#6 } \\
\hline Time & $\begin{array}{l}\& \text { Oil } \\
\text { Concn }\end{array}$ & Yield & Ash & Yield & Ash & Yield & Ash & Yield & Ash & Yield & Ash & Yield & Ash \\
\hline & $\%$ & $\%$ & $\%$ & $\%$ & $\%$ & $\%$ & $\%$ & $\%$ & $\%$ & $\%$ & $\%$ & $\%$ & $\%$ \\
\hline $10: 55$ & HS 0.75 & 82.2 & 10.1 & 13.8 & 14.4 & 2.6 & 30.8 & 0.7 & 38.0 & 0.6 & 66.1 & 0.1 & 70.9 \\
\hline $12: 25$ & Jet 0.84 & 69.6 & 9.0 & 21.9 & 12.5 & 5.6 & 20.5 & 1.7 & 29.7 & 0.9 & 50.1 & 0.4 & 55.9 \\
\hline $13: 25$ & Jet 0.76 & 66.6 & 9.1 & 24.7 & 12.0 & 5.8 & 17.5 & 2.0 & 29.6 & 0.7 & 52.8 & 0.3 & 54.1 \\
\hline $14: 55$ & Jet 0.70 & 50.6 & 7.6 & 25.2 & 9.0 & 14.8 & 10.4 & 5.6 & 10.7 & 3.7 & 12.3 & 0.1 & 11.6 \\
\hline $16: 25$ & HS 1.50 & 83.0 & 11.6 & 12.8 & 15.1 & 2.4 & 26.3 & 0.7 & 34.2 & 0.6 & 61.5 & 0.4 & 71.4 \\
\hline
\end{tabular}

During the L-7 test, verification of the process performance and determination of the flotation stage scale-up factor were accomplished by collecting small (1L) samples of the conditioned slurry from the plant during each testing period. These samples were used for batch flotation confirmatory tests. Results of the confirmatory tests are shown in Table 2-9 and are in very good agreement with the pilot plant tests. 


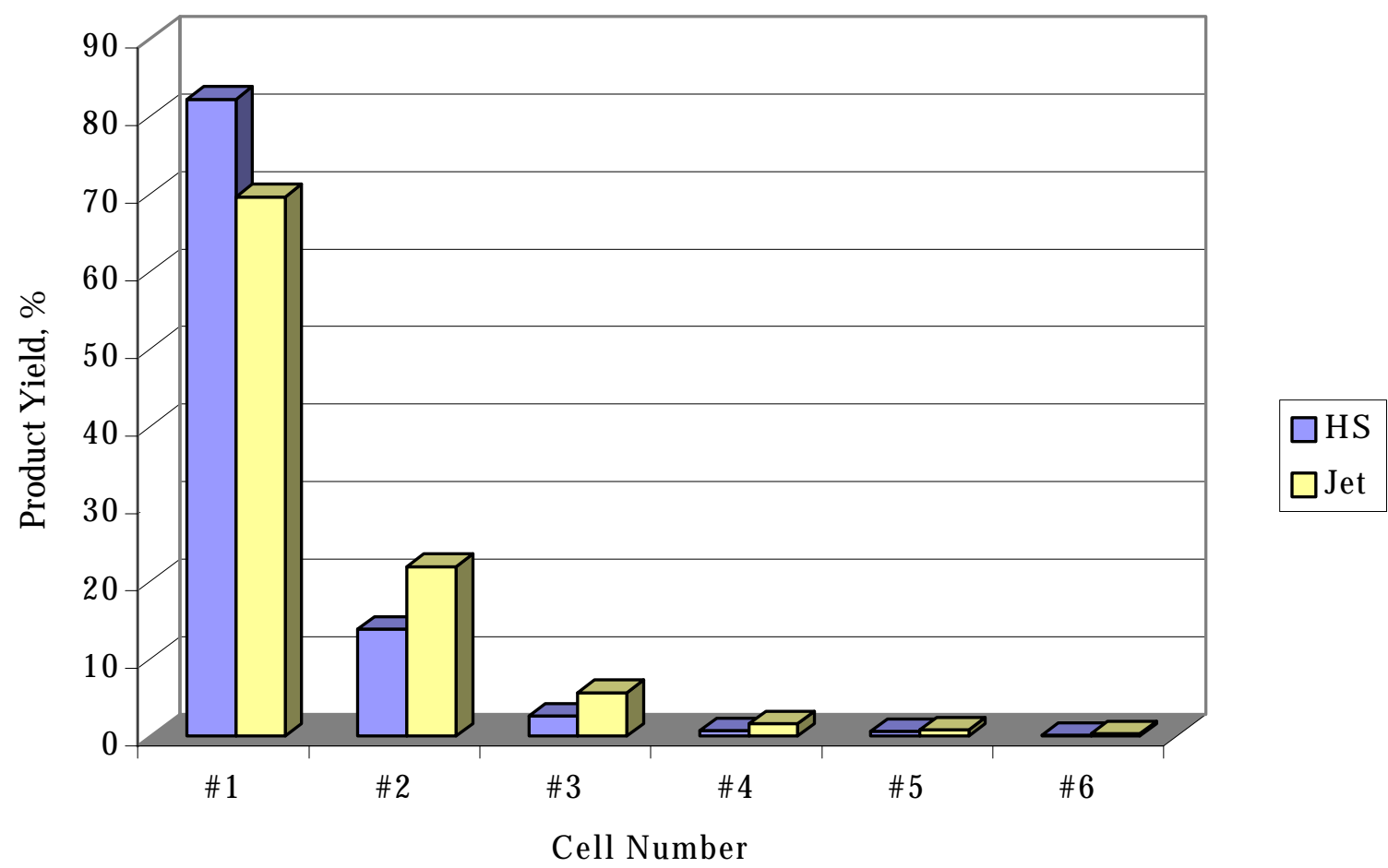

Figure 2-7. Coal Concentrate Distribution Along Flotation Bank at Oil Concentration of $0.75 \%$ - Test L-7

Table 2-9. Verification Batch Flotation for Test L-7

Process Conditions

High-Shear Mixer: Plant Sample Cs: $20 \%$ Oil : Diesel

Flotation Cell: $\quad 6 \mathrm{~min}, 1100 \mathrm{rpm}, \quad$ Cs: $6.5 \% \quad$ Frother: $\quad$ MIBC $250 \mathrm{~g} / \mathrm{t}$

\begin{tabular}{|c|c|c|c|c|c|c|c|c|}
\hline Time & $\begin{array}{c}\text { Option \& } \\
\text { Oil Concn } \\
\%\end{array}$ & $\begin{array}{c}\text { H S Mixer } \\
\text { Solids Concn } \\
\%\end{array}$ & $\begin{array}{c}\text { Feed Coal } \\
\text { Ash * } \\
\%\end{array}$ & $\begin{array}{c}\text { Product } \\
\text { Ash } \\
\%\end{array}$ & $\begin{array}{c}\text { Tailings } \\
\text { Ash } \\
\%\end{array}$ & $\begin{array}{c}\text { Yield } \\
\%\end{array}$ & $\begin{array}{c}\text { Recovery } \\
\%\end{array}$ & $\begin{array}{c}\text { AR } \\
\%\end{array}$ \\
\hline 11:00 & HS 0.74 & 21.4 & 19.0 & 11.7 & 84.7 & 90.2 & 98.1 & 38.7 \\
\hline $12: 30$ & Jet 0.84 & 20.9 & 18.9 & 11.5 & 84.9 & 90.1 & 98.1 & 39.1 \\
\hline 14:30 & Jet 0.76 & 22.8 & 19.2 & 10.0 & 51.8 & 78.3 & 87.0 & 47.9 \\
\hline 16:25 & HS 1.48 & 24.5 & 18.5 & 12.8 & 87.4 & 92.8 & 98.6 & 30.8 \\
\hline
\end{tabular}

* Reconstituted ash content value 


\subsection{RESULTS AND DISCUSSION}

\subsection{Coal Grinding System Stability}

During all runs, samples of coal slurry (discharge from the rod mill) were taken for particle size determination. The following are conditions for the rod mill operation used for all tests:

- coal feed throughput - $250 \mathrm{~kg} / \mathrm{h}$

- solids concentration - $50 \%$ (dry coal basis)

- rods charge $\quad-150 \mathrm{~kg}$

The target particle mass median diameter was in the range of $100 \mu \mathrm{m}$ to $110 \mu \mathrm{m}$.

Coal slurries collected during runs were analyzed for:

- particle size distribution (PSD) and mass median diameter $\left(\mathrm{d}_{50}\right)$, and

- coal slurry solids concentration

Table 3-1 presents particle size distribution and mass median diameter for runs L-5, L-6 and L-7.

Table 3-1. Feed Coal Particle Size Distribution for Rods Charge of $150 \mathrm{~kg}$

\begin{tabular}{|c|c|c|c|c|c|c|c|c|}
\hline $\begin{array}{c}\text { Particle Size } \\
\text { Fraction }\end{array}$ & \multicolumn{2}{|c|}{ L-5 } & \multicolumn{2}{c|}{ L-6 } & \multicolumn{2}{c|}{ L. D. \& Sampling Time } \\
\hline & \multicolumn{2}{|c|}{$16: 00$} & \multicolumn{2}{c|}{$12: 10$} & \multicolumn{2}{c|}{$14: 00$} & \multicolumn{2}{c|}{$16: 05$} \\
\hline $\begin{array}{c}\text { Sample S 200 } \\
\text { mm }\end{array}$ & $\%$ & $\begin{array}{c}\text { Cum. } \\
\%\end{array}$ & $\%$ & $\begin{array}{c}\text { Cum. } \\
\%\end{array}$ & $\%$ & $\begin{array}{c}\text { Cum. } \\
\%\end{array}$ & $\%$ & $\begin{array}{c}\text { Cum. } \\
\%\end{array}$ \\
\hline-0.038 & 28.4 & 28.4 & 21.7 & 21.7 & 26.8 & 26.8 & 28.4 & 28.4 \\
\hline $0.038-0.045$ & 2.2 & 30.6 & 2.4 & 24.1 & 1.4 & 28.2 & 1.7 & 30.1 \\
\hline $0.045-0.063$ & 8.5 & 39.1 & 5.6 & 29.7 & 7.9 & 36.2 & 7.4 & 37.5 \\
\hline $0.063-0.090$ & 11.7 & 50.8 & 7.6 & 37.3 & 10.6 & 46.7 & 9.3 & 46.8 \\
\hline $0.090-0.106$ & 4.4 & 55.2 & 3.4 & 40.7 & 2.1 & 48.8 & 2.2 & 49.0 \\
\hline $0.106-0.150$ & 11.9 & 67.2 & 9.7 & 50.4 & 14.2 & 63.0 & 14.1 & 63.1 \\
\hline $0.150-0.180$ & 5.1 & 72.2 & 5.9 & 56.3 & 5.0 & 68.0 & 5.3 & 68.4 \\
\hline $0.180-0.250$ & 13.4 & 85.5 & 10.9 & 67.2 & 13.9 & 81.9 & 15.0 & 83.4 \\
\hline $0.250-0.355$ & 10.1 & 95.6 & 17.6 & 84.9 & 11.5 & 93.4 & 10.4 & 93.8 \\
\hline+0.355 & 4.4 & 100 & 15.2 & 100.0 & 6.6 & 100.0 & 6.2 & 100.0 \\
\hline \hline
\end{tabular}

Evaluation of the results showed the following:

- for runs L-6 and L-7 the feed coal mass medium diameter was within the targeted range 
- during run L-5 the product mass median diameter was about $10 \%$ finer than the target range, however, because only one sample was taken for particle size determination, it could not be concluded that during the entire run coal particle size was finer than the targeted range

\subsection{Flotation Performance Evaluation}

The flotation cell installed at the $250 \mathrm{~kg} / \mathrm{h}$ bench-scale facility is a Denver model consisting of six chambers. As manufactured, the coal concentrate was collected into two chutes (three chambers per chute). In order to determine the kinetics of flotation, the outlets from the machine were modified. The change allowed to collect individual samples from each flotation chamber. The sampling was carried out for each agglomeration device (high-shear mixer or jet processor) and lasted one minute for each cell. Sample collection was carried out at the end of each testing period.

Coal concentrate samples from the individual chambers were collected during the following periods:

- for run L-5

$\begin{array}{cccc}\text { Sampling Time } & \text { Conditioning } & \text { Oil Concn } & \text { Frother } \\ \text { (Clock Time) } & \text { Equipment } & \% & \text { Addition, g/t } \\ 9: 50 & \text { High-Shear Mixer } & 2.5 & 250 \\ 11: 50 & \text { Jet Processor } & 2.5 & 250 \\ 12: 35 & \text { Jet Processor } & \text { No Oil } & 250 \\ 14: 40 & \text { Jet Processor } & 1.5 & 250 \\ 16: 10 & \text { High-Shear Mixer } & 1.7 & 250\end{array}$

- for run L-6

Sampling Time

(Clock Time)

$11: 30$

$13: 45$

- for run L-7

Sampling Time

(Clock Time)

10:55

$12: 25$

$13: 25$

$14: 55$

$16: 25$
Conditioning

Equipment

High-Shear Mixer

Jet Processor

Oil Concn
$\%$
1.5
1.5

Frother Addition, $\mathrm{g} / \mathrm{t}$

0

0

All collected samples were dried, weighed and analyzed for short proximate composition. The results obtained for each set of six samples are presented in Tables 3-2 and Figures 3-1 to 3-6. 
Table 3-2. Coal Concentrate Distribution and Ash Contents Along Flotation Bank

\begin{tabular}{|c|c|c|c|c|c|c|c|c|c|c|c|c|c|}
\hline \multirow{2}{*}{\begin{tabular}{|c} 
Test \& \\
Sapling \\
Time \\
Clock time
\end{tabular}} & \multirow[t]{2}{*}{$\begin{array}{c}\text { Option } \\
\& \text { Oil } \\
\text { Concen. }\end{array}$} & \multicolumn{2}{|c|}{ Cell \#1 } & \multicolumn{2}{|c|}{ Cell \#2 } & \multicolumn{2}{|c|}{ Cell \#3 } & \multicolumn{2}{|c|}{ Cell \#4 } & \multicolumn{2}{|c|}{ Cell \#5 } & \multicolumn{2}{|c|}{ Cell \#6 } \\
\hline & & Yield & Ash & Yield & Ash & Yield & Ash & Yield & Ash & Yield & Ash & Yield & Ash \\
\hline & $\%$ & $\%$ & $\%$ & $\%$ & $\%$ & $\%$ & $\%$ & $\%$ & $\%$ & $\%$ & $\%$ & $\%$ & $\%$ \\
\hline \multirow[t]{2}{*}{ L-5/9:50 } & HS - 2.5 & 82.1 & 12.1 & 13.3 & 14.6 & 2.7 & 26.4 & 0.8 & 34.4 & 0.7 & 61.9 & 0.4 & 70.7 \\
\hline & Cumulative & 82.1 & 12.1 & 95.4 & 12.4 & 98.1 & 12.8 & 98.9 & 13.0 & 99.6 & 13.4 & 100 & 13.6 \\
\hline \multirow[t]{2}{*}{ L-5/11:50 } & Jet -2.5 & 64.2 & 8.5 & 23.6 & 11.1 & 8.0 & 16.0 & 2.6 & 25.1 & 1.2 & 40.8 & 0.3 & 42.6 \\
\hline & Cumulative & 64.2 & 8.5 & 87.8 & 9.2 & 95.8 & 9.8 & 98.4 & 10.2 & 99.7 & 10.6 & 100 & 10.7 \\
\hline \multirow[t]{2}{*}{ L-5/16:10 } & HS -1.6 & 84.1 & 11.5 & 11.7 & 14.9 & 2.5 & 29.0 & 0.7 & 33.7 & 0.6 & 65.6 & 0.4 & 70.6 \\
\hline & Cumulative & 84.1 & 11.5 & 95.8 & 11.9 & 98.3 & 12.3 & 99.0 & 12.5 & 99.6 & 12.8 & 100 & 13.1 \\
\hline \multirow[t]{2}{*}{ L-7/16:25 } & HS - 1.5 & 83.0 & 11.6 & 12.8 & 15.1 & 2.4 & 26.3 & 0.6 & 34.2 & 0.7 & 61.5 & 0.4 & 71.4 \\
\hline & Cumulative & 83.0 & 11.6 & 95.8 & 12.1 & 98.2 & 12.4 & 98.9 & 12.6 & 99.5 & 12.9 & 100 & 13.1 \\
\hline \multirow[t]{2}{*}{ L-5/14:40 } & Jet -1.6 & 67.3 & 9.8 & 22.4 & 12.0 & 6.6 & 17.5 & 2.3 & 29.4 & 1.0 & 48.9 & 0.4 & 59.3 \\
\hline & Cumulative & 67.3 & 9.8 & 89.7 & 10.3 & 96.3 & 10.8 & 98.6 & 11.2 & 99.6 & 11.6 & 100 & 11.8 \\
\hline \multirow[t]{2}{*}{ L-7/10:55 } & HS - 0.75 & 82.2 & 10.1 & 13.8 & 14.4 & 2.6 & 30.8 & 0.7 & 38.0 & 0.6 & 66.1 & 0.1 & 70.9 \\
\hline & Cumulative & 82.2 & 10.1 & 96 & 10.7 & 98.6 & 11.2 & 99.3 & 11.4 & 99.9 & 11.8 & 100 & 11.8 \\
\hline \multirow[t]{2}{*}{ L-7/12:55 } & Jet -0.84 & 69.6 & 9.0 & 21.9 & 12.5 & 5.6 & 20.5 & 1.6 & 29.7 & 0.9 & 50.1 & 0.4 & 55.9 \\
\hline & Cumulative & 69.6 & 9.0 & 91.5 & 9.84 & 97.1 & 10.4 & 98.8 & 10.8 & 99.7 & 11.1 & 100 & 11.3 \\
\hline \multirow[t]{2}{*}{ L-7/13:25 } & Jet -0.76 & 66.6 & 9.1 & 24.7 & 12.0 & 5.8 & 17.5 & 2.0 & 29.6 & 0.7 & 52.8 & 0.2 & 54.1 \\
\hline & Cumulative & 66.6 & 9.1 & 91.3 & 9.9 & 97.1 & 10.3 & 99.1 & 10.7 & 99.8 & 11.0 & 100 & 11.1 \\
\hline L-5/12:35 & Jet-no oil & 10.5 & 7.0 & 10.7 & 6.2 & 11.7 & 6.0 & 7.2 & 5.15 & 12 & 6.3 & 47.4 & 12.4 \\
\hline L-7/14:55 & Jet-no frother & 50.6 & 7.6 & 25.3 & 9.0 & 14.8 & 10.4 & 5.5 & 10.7 & 3.7 & 12.3 & 0.1 & 11.6 \\
\hline
\end{tabular}

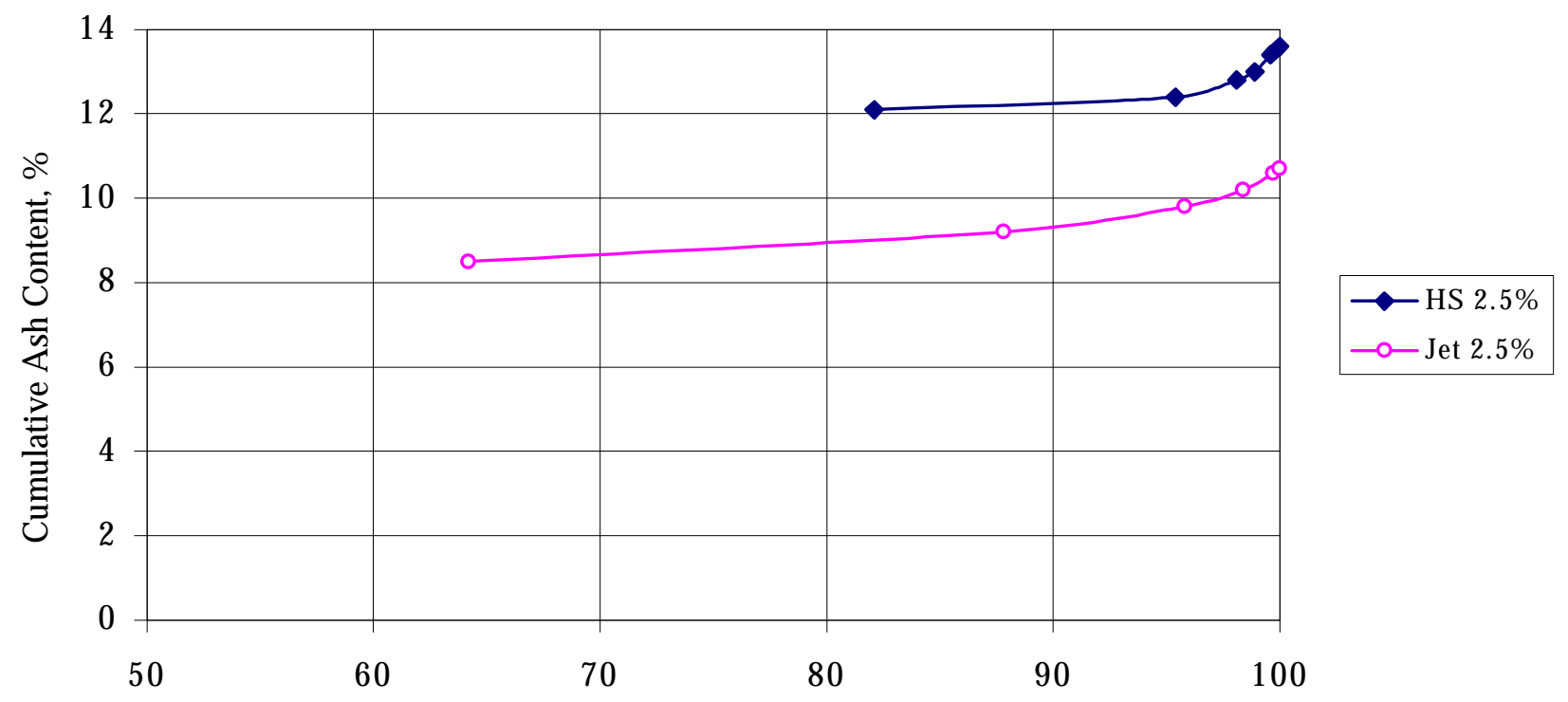

Cumulative Yield, \%

Figure 3-1. Flotation Stage Performance - Ash Content and Yield for Cumulative Products for Cells from \#1 to \#6, Oil Concentration of 2.5\% (Test L-5) 


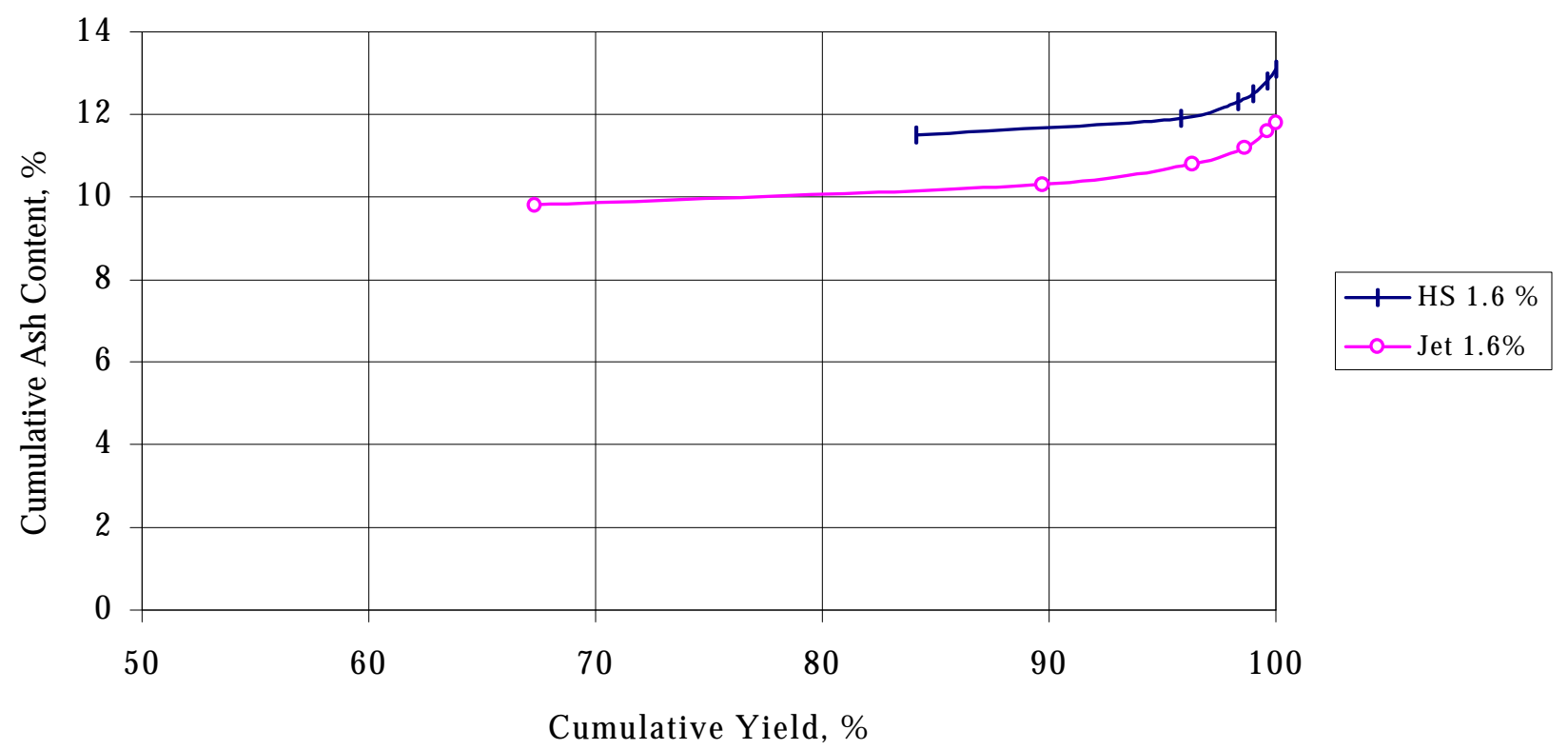

Figure 3-2. Flotation Stage Performance - Ash Content and Yield for Cumulative Products for Cells from \#1 to \#6, Oil Concentration of 1.6\% (Test L-5)

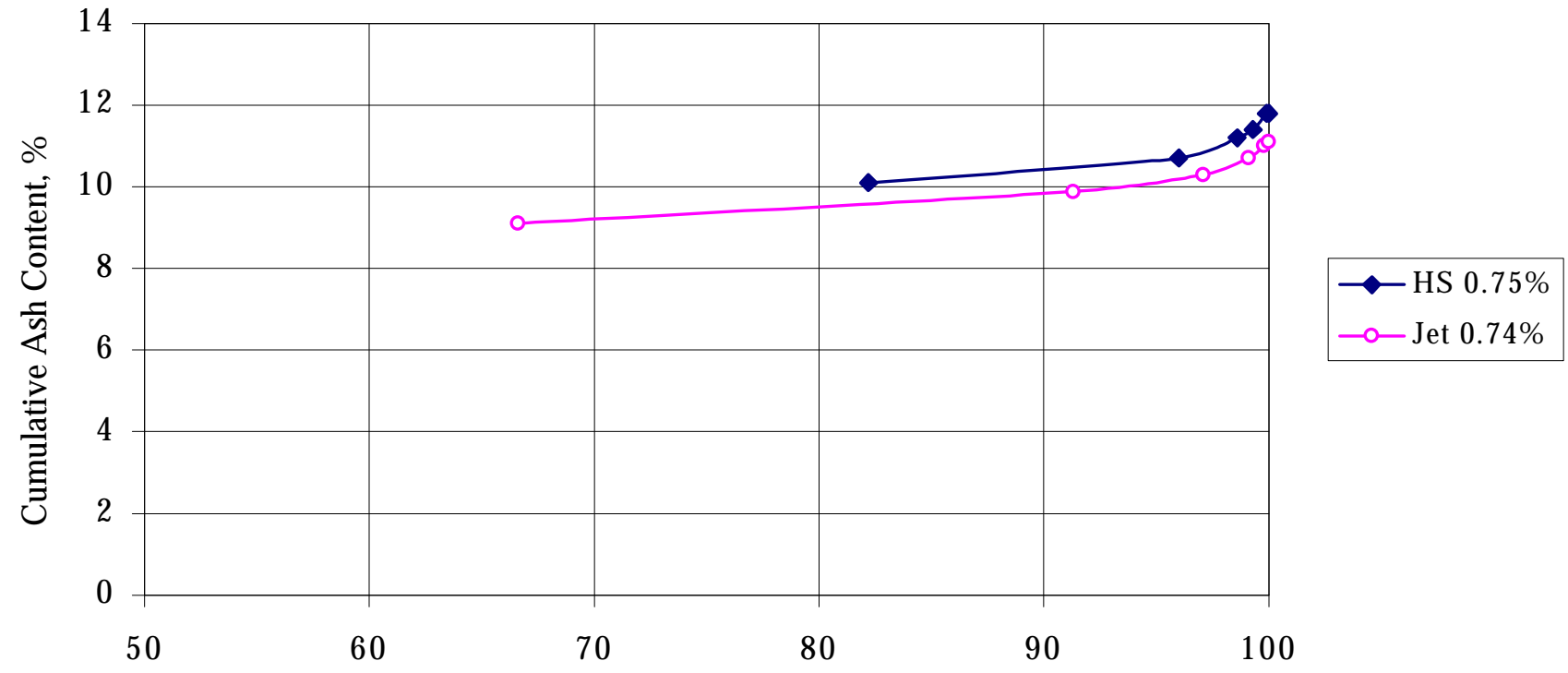

Cumulative Yield, \%

Figure 3-3. Flotation Stage Performance - Ash Content and Yield for Cumulative Products for Cells from \#1 to \#6, Oil Concentration of $0.75 \%$ (Test L-7)

In Figures 3-4 and 3-5 an effect of frother addition on the pattern of the flotation cell product distribution is shown. 


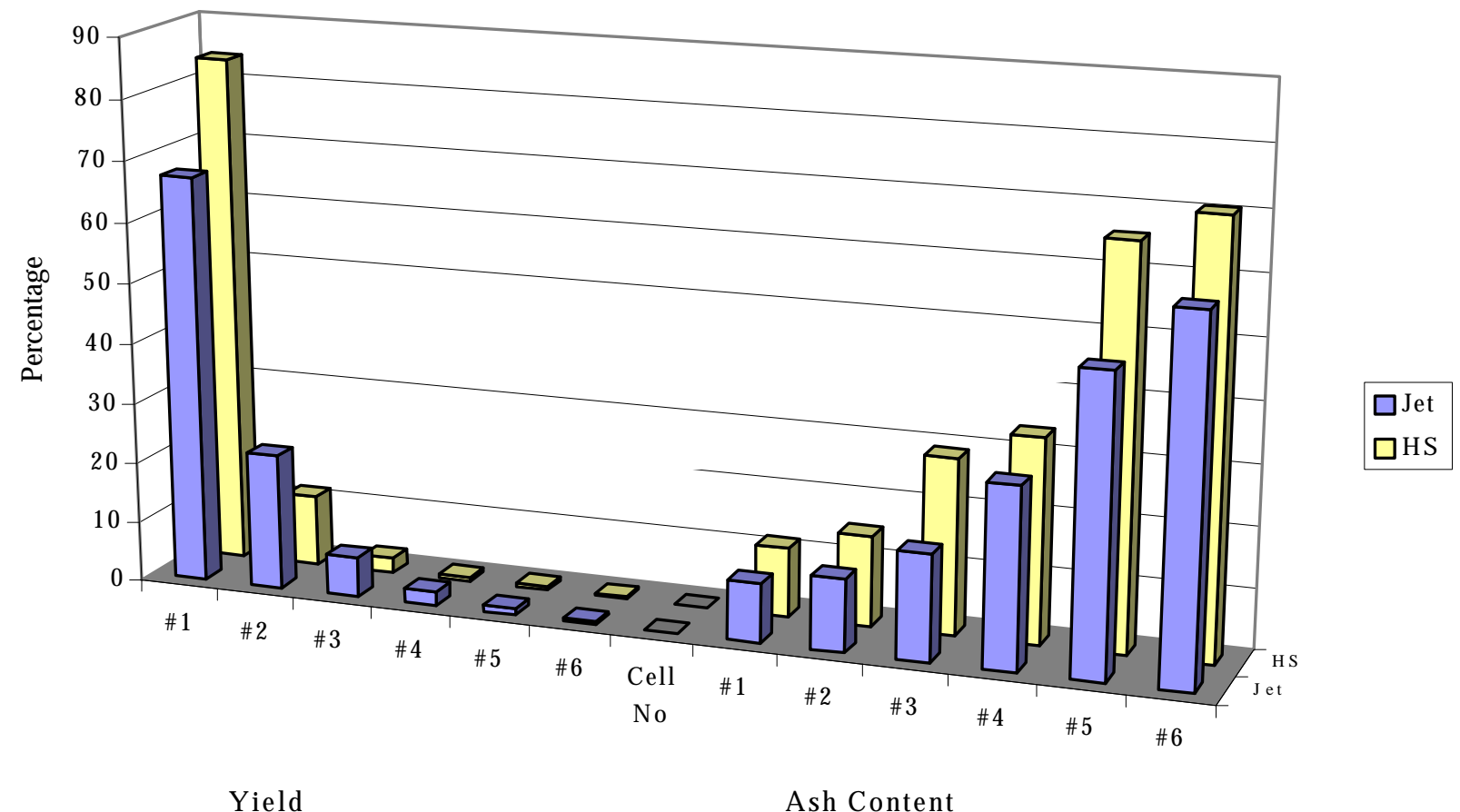

Figure 3-4. Coal Concentrate Distributions and Ash Contents Along Flotation Bank at Oil Concentration of $1.6 \%$ (Test L-5).

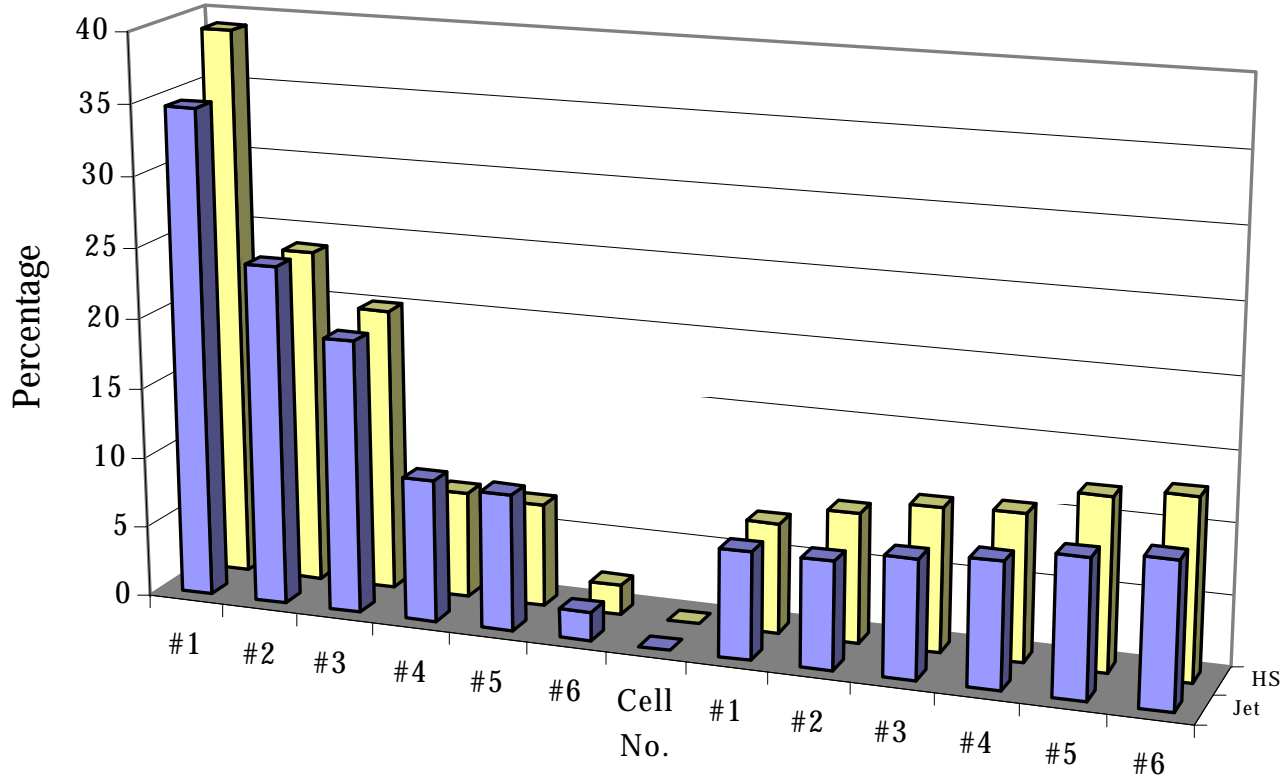

Yield

Ash Content

Figure 3-5. Coal Concentrate Distribution Along Flotation Bank for High-Shear Mixer and Jet Processor at Oil Concentration of $1.5 \%$ and no frother addition (Test L-6) 
Analysis of the test results for the flotation performance evaluation for runs L-5, L-6 and L-7 led to the following conclusions:

- For the high-shear mixer

- more than $95 \%$ of clean coal concentrate was collected from the two first cells regardless of oil concentration $(2.5 \%, 1.5 \%$ and $0.75 \%)$

- oil concentration had some impact on ash content recovered in the first cell; higher oil concentrations resulted in slightly higher ash contents

- ash content in the individual samples collected from cells significantly increased with the cell number and the product from the last six cells reached about $70 \%$; however, high ash contents in coal concentrate recovered from cells three to six have a negligible impact on ash content in the combined product because samples consist of a small proportion $(>5 \%)$ of the total whole concentrate

- For the jet processor

- about $88 \%, 90 \%$ and $91.5 \%$ of clean coal concentrate were collected from the first two cells with oil additions of $2.5 \%, 1.7 \%$ and $0.75 \%$, respectively; the yield of coal concentrate was lower by $5 \%$ when compared with the high-shear mixer

- ash content in the individual samples collected from the cells increased with cell number and reaching values of $42.6 \%, 59.3 \%$ and $55.9 \%$ for the product from the last cell for oil concentrations of $2.5 \%, 1.5 \%$ and $0.75 \%$, respectively

- For the jet processor with no oil addition

- the combined yield from the two first cells was as low as $21.2 \%$ (very low as compared with the testing periods when oil was used for coal conditioning (about 90 to 95\%))

- most of the coal concentrate (about 48\%) was collected from the last, sixth cell

- ash content of individual samples was $7 \%$ for cell number one and steadily increased to $12.4 \%$ for sample from cell number six

- For the jet processor with no frother addition

- about $76 \%$ of clean coal was collected from the first two cells; this was about $15 \%$ less when compared with testing periods when frother was applied

- for each cell, coal samples were characterized by lower ash contents when compared with the results achieved for testing periods when frother was utilized 


\subsection{Tests Reproducibility}

In Table 3-3 reproducibility of the tests results for two sets of different process conditions is presented. The comparison of the combustible recoveries, ash reductions and tailings ash contents show very good agreement.

In Table 3-4 and Figure 3-5 reproducibility of the flotation results is shown. The yields and ash contents for products from each cell are compared. Testing periods originating from two different runs (Tests L-5 and L-7) were performed at similar conditions. The high-shear mixer was used as a conditioning device and the oil addition was about $1.5 \%$.

Table 3-3. Test Reproducibility for Different Conditions

\begin{tabular}{|c|c|c|c|c|c|c|c|c|c|c|c|}
\hline \multirow[t]{2}{*}{$\begin{array}{l}\text { Test \& } \\
\text { Time }\end{array}$} & \multirow[t]{2}{*}{ Option } & \multirow[t]{2}{*}{$\begin{array}{c}\text { Oil } \\
\text { Concn }\end{array}$} & \multicolumn{2}{|c|}{$\begin{array}{c}\text { Slurry } \\
\text { S 200/201 }\end{array}$} & \multicolumn{2}{|c|}{$\begin{array}{c}\text { Product } \\
\text { S } 501\end{array}$} & \multicolumn{2}{|c|}{$\begin{array}{l}\text { Tailings } \\
\text { S } 502\end{array}$} & \multirow[t]{2}{*}{ Yield } & \multirow[t]{2}{*}{ Rec. } & \multirow[t]{2}{*}{ AR } \\
\hline & & & Cs & Ash & $\mathrm{Cs}$ & Ash & Cs & Ash & & & \\
\hline & & $\%$ & $\%$ & $\%$ & $\%$ & $\%$ & $\%$ & $\%$ & $\%$ & $\%$ & $\%$ \\
\hline L-5/16:15 & HS & 1.62 & 20.5 & 16.9 & 23.5 & 11.2 & 0.9 & 85.2 & 92.3 & 98.6 & 33.8 \\
\hline L-716:30 & HS & 1.50 & 24.2 & 18.5 & 24.0 & 11.3 & 1.2 & 85.9 & 90.4 & 98.3 & 38.6 \\
\hline L-6/11:45 & $\begin{array}{l}\text { Jet, no } \\
\text { frother }\end{array}$ & 1.39 & 19.2 & 20.1 & 30.2 & 7.9 & 1.9 & 48.6 & 70.0 & 80.7 & 60.7 \\
\hline L-7/15:00 & $\begin{array}{l}\text { Jet, no } \\
\text { frother }\end{array}$ & 0.69 & 24.7 & 21.7 & 31.2 & 8.8 & 2.7 & 51.0 & 69.5 & 81.0 & 59.4 \\
\hline
\end{tabular}

Table 3-4. Flotation Cell Reproducibility at Medium Oil Concentration for High-Shear Mixer

\begin{tabular}{|c|c|c|c|c|c|c|c|c|c|c|c|c|c|}
\hline $\begin{array}{c}\text { Test \& } \\
\text { Time }\end{array}$ & $\begin{array}{c}\text { Oil } \\
\text { Concn }\end{array}$ & \multicolumn{2}{c|}{ Cell \#1 } & \multicolumn{2}{c|}{ Cell \#2 } & \multicolumn{2}{c|}{ Cell \#3 } & \multicolumn{2}{c|}{ Cell \#4 } & \multicolumn{2}{c|}{ Cell \#5 } & \multicolumn{2}{c|}{ Cell \#6 } \\
& $\%$ & $\%$ & $\%$ & $\%$ & $\%$ & $\%$ & $\%$ & $\%$ & $\%$ & $\%$ & $\%$ & $\%$ & $\%$ \\
\hline L-5/16:10 & 1.6 & 84.1 & 11.5 & 11.7 & 14.9 & 2.5 & 29.0 & 0.7 & 33.7 & 0.62 & 65.6 & 0.38 & 70.6 \\
L-7/16:25 & 1.5 & 83 & 11.6 & 12.8 & 15.1 & 2.41 & 26.3 & 0.7 & 34.2 & 0.58 & 61.5 & 0.42 & 71.4 \\
\hline L-6/11:30 & $1.5($ no & 39.1 & 7.8 & 23.8 & 9.2 & 20.1 & 10.2 & 7.5 & 10.4 & 7.3 & 12.2 & 2.1 & 12.8 \\
L-7/14:55 & $\begin{array}{c}1.5(\text { no } \\
\text { frother) }\end{array}$ & 50.6 & 7.6 & 25.2 & 9.0 & 14.8 & 10.4 & 5.6 & 10.7 & 3.7 & 12.3 & 0.1 & 11.6 \\
\hline
\end{tabular}




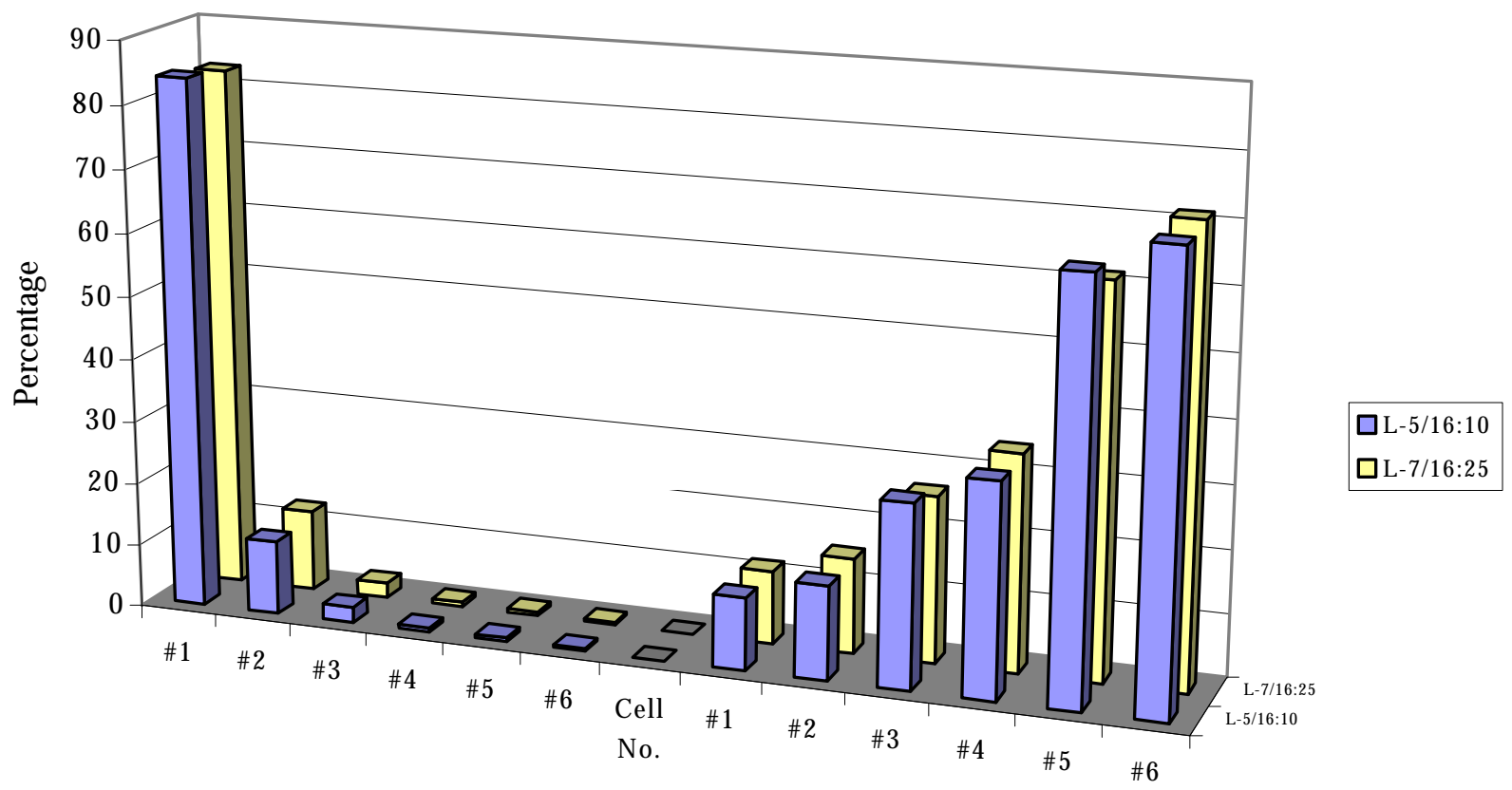

Yield

Ash Content

Figure 3-6. Flotation Cell Performance Reproducibility at Oil Concentration of 1.5\%

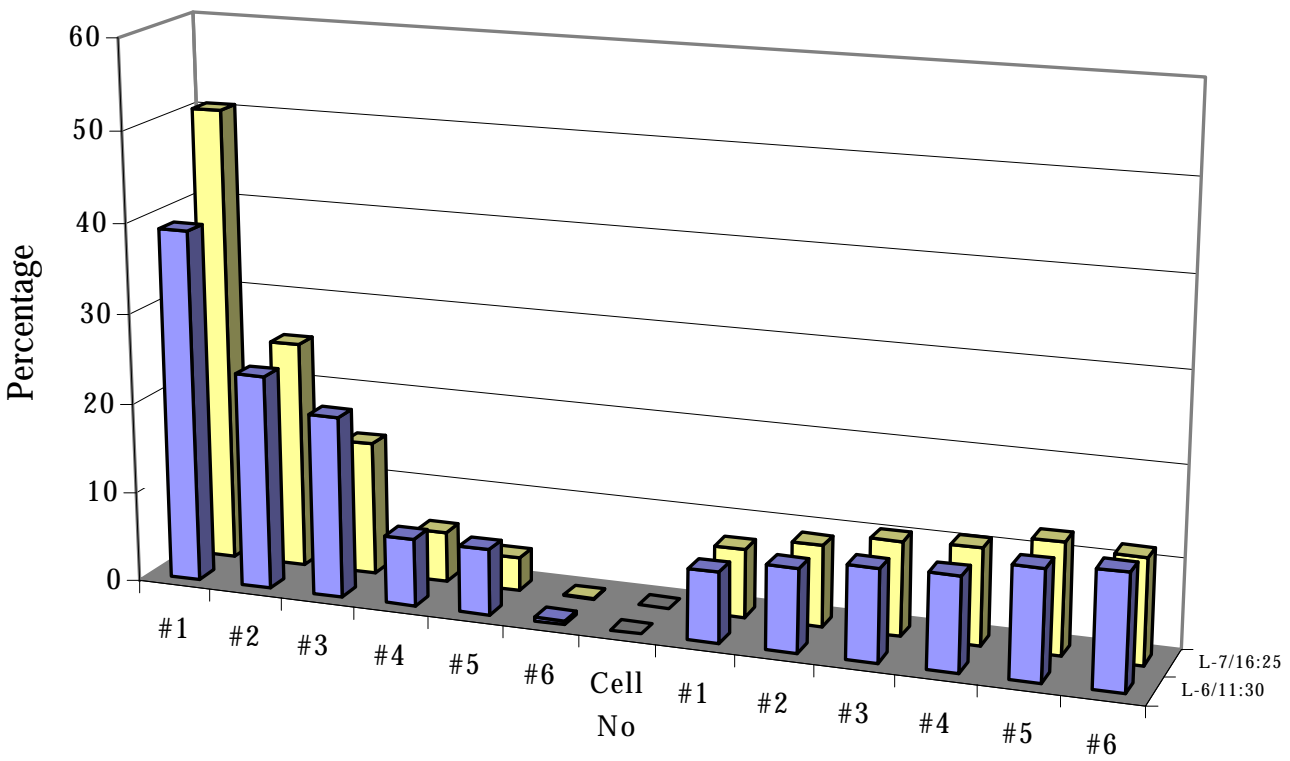

Yield

Ash Content

Figure 3-7. Flotation Cell Performance Reproducibility without Frother at Oil Concentration of $1.5 \%$ 


\subsection{Batch-Scale Flotation Confirmatory Tests}

The results presented in Table 3-4 show the comparison of the batch- and bench-scale flotation. It should be pointed out that both flotation units used are Denver machine and are characterized by the same mixer design and geometry.

Table 3-5. Comparison of the Flotation Verification Batch-Scale Tests with Pilot Plant Tests

\begin{tabular}{|c|c|l|l|c|c|c|c|c|}
\hline $\begin{array}{c}\text { Test } \\
\text { No }\end{array}$ & $\begin{array}{c}\text { Sampling } \\
\text { Time }\end{array}$ & System & $\begin{array}{c}\text { Oil } \\
\text { Concentration } \\
\%\end{array}$ & $\begin{array}{c}\text { Feed Coal } \\
\text { Ash } \\
\%\end{array}$ & $\begin{array}{c}\text { CM } \\
\text { Recovery } \\
\%\end{array}$ & $\begin{array}{c}\text { Product } \\
\text { Ash } \\
\%\end{array}$ & $\begin{array}{c}\text { Ash } \\
\text { Reduction } \\
\%\end{array}$ & $\begin{array}{c}\text { Tailings } \\
\text { Ash } \\
\%\end{array}$ \\
\hline L-5 & $10: 05$ & Plant & 2.35 & 16.4 & 98.4 & 9.2 & 44.0 & 85.6 \\
& $10: 05$ & Batch & 2.35 & 17.0 & 98.6 & 11.5 & 32.4 & 83.8 \\
\hline L-5 & $12: 05$ & Plant & 2.48 & 17.9 & 96.0 & 10.1 & 43.6 & 73.2 \\
& $12: 05$ & Batch & 2.48 & 18.0 & 97.0 & 12.6 & 29.7 & 71.8 \\
\hline L-5 & $13: 10$ & Plant & 1.54 & 16.7 & 98.2 & 10.8 & 35.6 & 82.0 \\
& 13.15 & Batch & 1.52 & 17.1 & 97.9 & 11.1 & 35.4 & 79.6 \\
\hline L-5 & $14: 45$ & Plant & 1.72 & 17.9 & 98.1 & 11.1 & 37.9 & 83.4 \\
& $14: 40$ & Batch & 1.70 & 21.4 & 97.3 & 11.4 & 46.9 & 76.6 \\
\hline L-5 & $16: 15$ & Plant & 1.62 & 16.9 & 98.6 & 11.2 & 33.8 & 85.2 \\
& $16: 15$ & Batch & 1.62 & 18.9 & 98.2 & 12.7 & 32.6 & 83.2 \\
\hline L-7 & $16: 30$ & Plant & 1.50 & 18.5 & 98.3 & 11.3 & 38.6 & 85.9 \\
& $16: 25$ & Batch & 1.48 & 18.5 & 98.6 & 12.8 & 30.8 & 87.4 \\
\hline L-7 & $11: 00$ & Plant & 0.75 & 18.7 & 98.4 & 11.8 & 37.1 & 86.2 \\
& $11: 00$ & Batch & 0.75 & 19.0 & 98.1 & 11.7 & 38.7 & 84.5 \\
\hline L-7 & 12.30 & Plant & 0.84 & 19.8 & 97.3 & 11.6 & 41.4 & 83.4 \\
& $12: 30$ & Batch & 0.84 & 18.9 & 98.1 & 11.5 & 39.1 & 84.9 \\
\hline
\end{tabular}

Evaluation and comparison of batch- and bench-scale flotation data led to the following conclusions:

- combustibles recoveries in most cases exceeded 98\%

- in terms of ash content, the laboratory flotation machine generated product with slightly higher ash contents, that affected ash reduction (lower as compared with pilot plant flotation)

- tailings ash contents were dependent on combustibles recovery and product ash content and usually were higher for pilot plant tests. 


\subsection{Comparison of High-Shear Mixer and Jet Processor Performance}

To compare performance of high-shear mixer and jet processor the most important parameters, like product ash, tailings ash and combustibles recovery are presented in Table 3-6.

Table 3-6. Effect of Operating Conditions on Process Performance

\begin{tabular}{|l|c|c|c|c|c|c|}
\hline Option & $\begin{array}{c}\text { Oil Concn } \\
\%\end{array}$ & $\begin{array}{c}\text { Solids } \\
\text { Concn } \\
\%\end{array}$ & $\begin{array}{c}\text { Product Ash } \\
\%\end{array}$ & $\begin{array}{c}\text { Ash } \\
\text { Reduction } \\
\%\end{array}$ & $\begin{array}{c}\text { Tailings Ash } \\
\%\end{array}$ & $\begin{array}{c}\text { Recovery } \\
\%\end{array}$ \\
\hline High-Shear & 0.75 & 20 & $11.7-12.4$ & $37.1-40.8$ & $85.1-86.2$ & $97.9-98.4$ \\
Jet & 0.75 & 20 & $10.3-11.6$ & $41.4-46.3$ & $83.4-83.9$ & $97.3-97.9$ \\
\hline High-Shear & 1.5 & 20 & $10.7-12.8$ & $33.8-37.9$ & $83.3-85.2$ & $98.2-98.6$ \\
Jet & 1.5 & 20 & $10.1-11.3$ & $35.2-39.0$ & $81.3-83.4$ & $98.0-98.2$ \\
\hline High-Shear & 2.5 & 20 & $9.2-11.5$ & $38.7-46.8$ & $85.0-86.1$ & $98.0-98.4$ \\
Jet & 2.5 & 20 & $9.7-10.1$ & $42.9-45.7$ & $73.2-79.9$ & $96.0-97.3$ \\
\hline
\end{tabular}

The Aglofloat process performance for Luscar Mine coal is characterized by very high combustibles recovery at moderate ash reduction in the order of $40 \%$. Based on the results obtained it has been found that replacement of the high-shear mixer with a jet processor would result in relatively small changes in Aglofloat process performance. For high oil concentration $(2.5 \%)$ high-shear mixer provided higher combustibles recovery (by about $2 \%$ ), however this was accompanied by lower reduction when compare with jet processor. For medium oil concentrations (with $1.5 \%$ ) combustibles recovery was very similar for both devices, while slightly better ash reduction was observed for jet processor. For low oil addition, $(0.75 \%)$ combustibles recovery was slightly higher for high-shear mixer but this was accompanied by lower ash reduction when compare with jet processor. For all levels of oil concentration, high-shear mixer generated tailings with higher ash content as compared with jet processor tailings.

Analysis of results obtained for tests L-5, L-6 and L-7 revealed that replacement of the high-shear mixer with a jet processor resulted in:

- a slight decrease in combustibles recovery, and

- marginal product quality improvement

Based on the tests performed it was also concluded that:

- sufficient time to fully stabilize the plant operation after the major process parameter changes is 1.5 hours

- process performance reproducibility is very good

- results of the batch flotation confirmatory test are in a good agreement with the pilot plant test results

A general conclusion is that costly and energy demanding high-shear mixer might be replaced with a jet processor without sacrifice a lot in terms of the Aglofloat process performance. 


\subsection{PRELIMINARY POC EQUIPMENT AND DESIGN PACKAGE}

Based on the specification package prepared by ARC, the Thermo Design Engineering designed a Proof-of-Concept (POC-Scale) agglomeration unit to be demonstrated and tested at commercial coal preparation plant.

The POC-Scale unit is designed for a nominal capacity throughput of $3 \mathrm{t} / \mathrm{hr}$ of dry coal fines and is capable of being operated on a shortly daily schedule or longer $24 \mathrm{hr} /$ day basis.

The plant is designed as a self-contained, skid-mounted unit. It is assumed that unit will be transported on trailers and will require partial assembly on the host site. The plant is designed to operate under semi-automated control and require only infrequent operator action.

The unit can be operated at three different configuration:

- Case A - non densified cyclone overflow used as a unit feed

- Case B - densified cyclone overflow used as a unit feed

- Case $\mathrm{C}$ - coal slurry prepared from pond fines used as a unit feed

The design package consists of the following sections:

Section I Overview

Section II Skid Packaging

Section III Instrumentation Details

Section IV Control System

Section V Electrical System

Section VI Process \& Instrumentation Diagrams

Section VII Plant Layout

Section VIII Vessel Fabrication Drawings

Copies of the preliminary POC equipment and design package were submitted to DOE Contract Manager, and under separate cover to ADD Document Control Office.

After receiving comments/suggestions, a final POC equipment and design will be prepared. 


\section{LIST OF ABBREVIATIONS AND ACRONYMS}

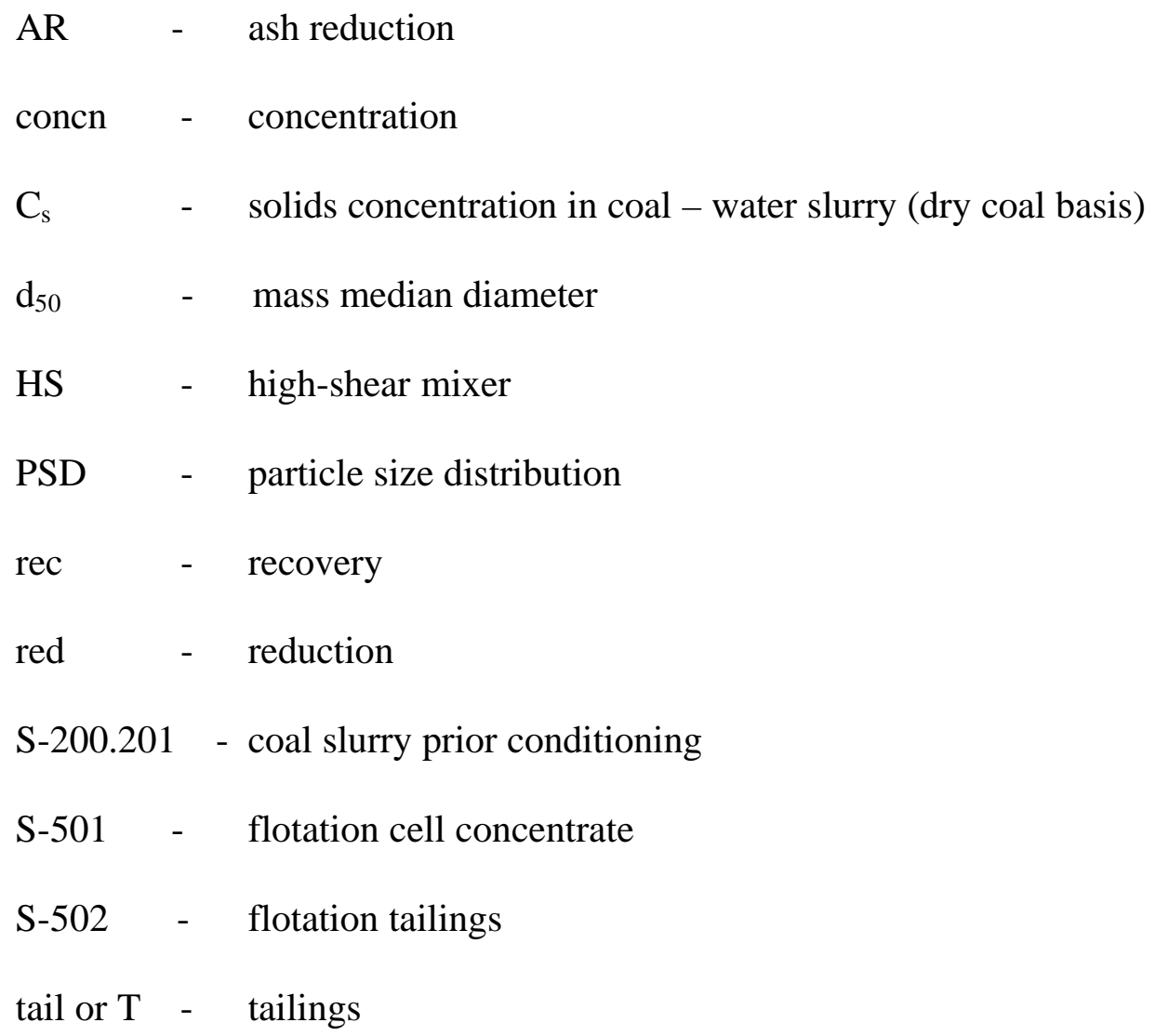

